\title{
Changes in the Subantarctic Mode Water Properties and Spiciness in the Southern Indian Ocean based on Argo Observations $\mathscr{O}$
}

\author{
Ying Zhang, ${ }^{\mathrm{a}, \mathrm{b}}$ Yan Du, ${ }^{\mathrm{a}, \mathrm{b}, \mathrm{c}}$ TANgdong Qu, ${ }^{\mathrm{d}}$ Yu Hong, ${ }^{\mathrm{a}, \mathrm{b}}$ Catia M. Domingues,,${ }^{\mathrm{e}, \mathrm{f}, \mathrm{g}}$ AND Ming Feng ${ }^{\mathrm{h}, \mathrm{i}}$

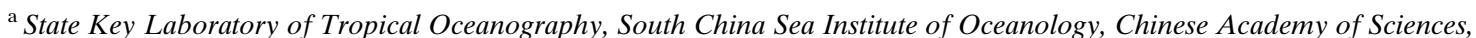 \\ Guangzhou, China \\ ${ }^{\mathrm{b}}$ Southern Marine Science and Engineering Guangdong Laboratory, Guangzhou, China \\ ${ }^{\mathrm{c}}$ College of Marine Science, University of Chinese Academy of Sciences, Beijing, China \\ ${ }^{\mathrm{d}}$ Joint Institute for Regional Earth System Science and Engineering, University of California, Los Angeles, Los Angeles, California \\ ${ }^{\mathrm{e}}$ National Oceanography Centre, Southampton, United Kingdom \\ ${ }^{\mathrm{f}}$ Centre of Excellence for Climate Extremes, Australian Research Council, Hobart, Tasmania, Australia \\ ${ }^{\mathrm{g}}$ Institute for Marine and Antarctic Studies, University of Tasmania, Hobart, Tasmania, Australia \\ ${ }^{\mathrm{h}}$ CSIRO Oceans and Atmosphere, Crawley, Western Australia, Australia \\ ${ }^{\mathrm{i}}$ Centre for Southern Hemisphere Oceans Research, Hobart, Tasmania, Australia
}

(Manuscript received 17 October 2020, in final form 10 March 2021)

\begin{abstract}
The Subantarctic Mode Water (SAMW) plays an essential role in the global heat, freshwater, carbon, and nutrient budgets. In this study, decadal changes in the SAMW properties in the southern Indian Ocean (SIO) and associated thermodynamic and dynamic processes are investigated during the Argo era. Both temperature and salinity of the SAMW in the SIO show increasing trends during 2004-18. A two-layer structure of the SAMW trend, with more warm and salty light SAMW but less cool and fresh dense SAMW, is identified. The heaving and spiciness processes are important but have opposite contributions to the temperature and salinity trends of the SAMW. A significant deepening of isopycnals (heaving), peaking at $\sigma_{\theta}=26.7-26.8 \mathrm{~kg} \mathrm{~m}^{-3}$ in the middle layer of the SAMW, expands the warm and salty light SAMW and compresses the cool and fresh dense SAMW corresponding to the change in subduction rate during 2004-18. The change in the SAMW subduction rate is dominated by the change in the mixed layer depth, controlled by the changes in wind stress curl and surface buoyancy fluxes. An increase in the mixed layer temperature due to weakening northward Ekman transport of cool water leads to a lighter surface density in the SAMW formation region. Consequently, density outcropping lines in the SAMW formation region shift southward and favor the intrusion and entrainment of the cooler and fresher Antarctic surface water from the south, contributing to the cooling/freshening trend of isopycnals (spiciness). Subsequently, the cooler and fresher SAMW spiciness anomalies spread in the SIO via the subtropical gyre.
\end{abstract}

SIGNIFICANCE STATEMENT: Subantarctic Mode Water is a distinct water mass with vertically uniform properties in the Southern Hemisphere's subtropical gyres. Climate change is imprinted in the SAMW through the ventilation at the base of the winter mixed layer. The ocean modulation associated with wind-forced large-scale waves and circulation also plays an essential role in heat, salinity, and water mass redistribution. A net increase in volume-weighted potential temperature and salinity of the SAMW is found during the Argo era since 2004, resulting from a combination of climate change and ocean modulation through opposite heaving and spiciness processes. This study improves our understanding of the dynamics and thermodynamics involved in the SAMW formation during rapid climate change.

KEYWORDS: Water masses/storage; Air-sea interaction; Ocean dynamics; Oceanic mixed layer; Currents; Climate variability

\section{Introduction}

The Subantarctic Mode Water (SAMW) is characterized by layers of relatively uniform water mass properties (thermostads, halostads, and pycnostads) over a large ocean volume (Hanawa and Talley 2001; McCartney 1979). The SAMW is formed by convective overturn, arising from buoyancy loss and wind forcing during winter in the deep mixed layers of the

Supplemental information related to this paper is available at the Journals Online website: https://doi.org/10.1175/JPO-D-200254.s1.

Corresponding author: Yan Du, duyan@scsio.ac.cn
Subantarctic Zone, between the Subtropical and Subantarctic Fronts (Downes et al. 2010; Holte et al. 2012; Speer and Forget 2013). The deep winter mixed layers appear as "pools" with uneven coverage around the Southern Hemisphere oceans (Sallée et al. 2010a,b), with depths ranging from 200 to $300 \mathrm{~m}$ in the southern Atlantic and southwestern Indian Oceans, and to more than $500 \mathrm{~m}$ in the southeastern Indian and southern Pacific Oceans (Dong et al. 2008; Li and Lee 2017; McCartney 1982). Processes involved in the deep winter mixed layers include air-sea buoyancy fluxes, lateral circulation, Ekman and eddy-induced transport, diapycnal mixing, and upwelling (Holte et al. 2012; Sallée et al. 2008a, 2010a, 2006; Sloyan et al. 2010). The SAMW enters the interior ocean through subduction, allowing fluid to pass irreversibly from the winter mixed layers into the permanent thermocline. The subduction 
of the SAMW is driven by lateral induction and Ekman pumping (Downes et al. 2017; Karstensen and Tomczak 1997; Karstensen and Quadfasel 2002a; Qu et al. 2020; Sallée and Rintoul 2011; Sallée et al. 2010a, 2012). The subducted SAMW is transported eastward with the Antarctic Circumpolar Current (ACC) and northward into the adjacent subtropical gyres, contributing to the thermocline ventilation (Sloyan and Rintoul 2001a,b; Speer and Forget 2013; Talley 2013). As part of the upper limb of the global overturning circulation, the SAMW plays an essential role in the global heat, freshwater, carbon, and nutrient budgets (DeVries et al. 2017; Gao et al. 2018; Jones et al. 2016; McCartney 1982; Sabine et al. 2004; Sallée et al. 2012; Sarmiento et al. 2004; Sloyan and Rintoul 2001b).

In the past decade, most of the ocean warming measured by the near-global array of Argo floats occurred in the Southern Hemisphere, largely associated with changes in SAMW in the southern Pacific and Indian Oceans (Desbruyères et al. 2017; Gao et al. 2018; Häkkinen et al. 2016; Kolodziejczyk et al. 2019; Llovel and Terray 2016; Portela et al. 2020; Roemmich et al. 2015). The SAMW formation is vigorous in the south Indian Ocean (SIO), attracting much attention recently. Speer et al. (1997) suggests that the SAMW formation rate in the SIO in the density range of $26.5-27.2 \mathrm{~kg} \mathrm{~m}^{-3}$ is $25 \mathrm{~Sv}\left(1 \mathrm{~Sv} \equiv 10^{6} \mathrm{~m}^{3} \mathrm{~s}^{-1}\right)$, with a peak at $26.9 \mathrm{~kg} \mathrm{~m}^{-3}$. An estimate of $19.8 \mathrm{~Sv}$ in the density range of $26.52-26.80 \mathrm{~kg} \mathrm{~m}^{-3}$ is reported by Marsh et al. (2000a) using an isopycnal ocean circulation model. Sloyan and Rintoul $(2001 \mathrm{a}, \mathrm{b})$ provide an estimate of $24 \mathrm{~Sv}$ in the density range of 26 $26.8 \mathrm{~kg} \mathrm{~m}^{-3}$ through surface fluxes and diapycnal mixing using an inverse model. A similar assessment of 20-26 Sv between 25.7 and $26.8 \mathrm{~kg} \mathrm{~m}^{-3}$ is also given by Karstensen and Quadfasel (2002b). Cerovečki and Mazloff (2016) indicate a SAMW formation rate in the SIO of 7.6 Sv by heat flux, including surface heat flux and heat flux due to diapycnal mixing, and $9.6 \mathrm{~Sv}$ by freshwater flux, including surface freshwater flux and freshwater flux due to diapycnal mixing, in the density range of 26.7$27.2 \mathrm{~kg} \mathrm{~m}^{-3}$, with a peak at $26.8 \mathrm{~kg} \mathrm{~m}^{-3}$, based on a framework in which water mass transformation from one isopycnal layer to an adjacent one by air-sea buoyancy fluxes or diapycnal mixing is estimated.

The deep winter mixed layers in the SIO extend from $50^{\circ} \mathrm{E}$ to south of Australia and are confined to the Subantarctic Zone (Koch-Larrouy et al. 2010; Sallée et al. 2006), where three classes of SAMW are found in different ventilation zones: 1) the light SAMW $\left(\sigma_{\theta}<26.7 \mathrm{~kg} \mathrm{~m}^{-3}, \mathrm{~L}-\mathrm{SAMW}\right)$ subducted west of the Kerguelen Plateau, 2$)$ the medium SAMW $\left(\sigma_{\theta}=26.7-\right.$ $\left.26.8 \mathrm{~kg} \mathrm{~m}^{-3}, \mathrm{M}-\mathrm{SAMW}\right)$ southwest of Australia, and 3) the dense SAMW $\left(\sigma_{\theta}>26.8 \mathrm{~kg} \mathrm{~m}^{-3}\right.$, D-SAMW), also the deepest, south of the Australian coast (Cerovečki et al. 2013; Fine 1993; Hanawa and Talley 2001; Herraiz-Borreguero and Rintoul 2011; Koch-Larrouy et al. 2010; McCartney 1982; Rintoul and Sokolov 2001; Talley 1999; Thompson and Edwards 1981; Wong 2005). Waters in the SAMW formation regions in the SIO originate from the Atlantic, the Agulhas Retroflection region, the Leeuwin Current, the Tasman Sea, and the Antarctic Surface Waters (Koch-Larrouy et al. 2010). After subduction, two SAMW pathways have been identified in the SIO based on the observations: a westward path along the South Australian coast and a westward path across the
South Australian Basin (Bye 1972, 1983; Fine et al. 2008; Koch-Larrouy et al. 2010; Middleton and Bye 2007).

Argo observations show a two-layer density structure in the trend of the SAMW volume in the SIO, with an upper-layer volume gain and a lower-layer volume loss over the past decade (Hong et al. 2020; Kolodziejczyk et al. 2019; Portela et al. 2020). However, variability and change in temperature and salinity of the SAMW in the SIO are still poorly documented. This variability and change in the SAMW provide crucial memory for the climate system globally and regionally (Banks et al. 2002).

Variability and change of temperature and salinity can be decomposed into variability and change associated with vertical migration of isopycnal surfaces (heaving) and variability and change along isopycnal surfaces (spiciness) (Bindoff and McDougall 1994; McDougall and Krzysik 2015). Heaving can arise from adiabatic vertical movement of waters, anomalous wind forcing, and water mass renewal (Clément et al. 2020; Häkkinen et al. 2016). Spiciness can be generated by variability and change in the mixed layer, such as air-sea interface fluxes, convective mixing, and anomalous subduction ( $\mathrm{Li}$ and Wang 2015; Luo 2005; Nagura and Kouketsu 2018; Nonaka and Sasaki 2007; Yeager and Large 2004, 2007). Spiciness can also result from variability and change in the interior ocean, for example, anomalous advection across the mean isopycnal temperature-salinity front (Schneider 2000). Observed variations in properties of a water mass on isopycnal surfaces (spiciness) have commonly been attributed to variations of surface temperature and salinity in the water's formation regions (Arbic and Brechner Owens 2001; Bindoff and Church 1992; Bryden et al. 2003, 1996; Johnson and Orsi 1997; Wong et al. 1999). Subsurface spiciness variations are advected by geostrophic currents in the ocean interior, conveying midlatitude signals to low latitudes, thus playing an essential role in global and regional climate variability. Therefore, SAMW is regarded as a good indicator of climate change (Banks et al. 2002).

In this study, we investigate the relative roles of the heaving and spiciness processes in the variability and change of the SAMW properties in response to atmospheric/oceanic dynamics and thermodynamics, providing a new insight for exploring variability and change of the SAMW and its impact on the subtropical thermocline waters in the SIO.

The remainder of this paper is arranged as follows. Section 2 describes the datasets and methods for calculating changes in the SAMW properties. The observed changes in the SIO and the SAMW properties and associated thermodynamic and dynamic processes are described in section 3. Section 4 examines the subsurface spiciness in the SIO. Section 5 discusses the possible dynamic processes affecting the SAMW properties. Conclusions are found in section 6 .

\section{Data and method}

\section{a. Data}

To decompose ocean temperature and salinity changes into the heaving and spiciness contributions from 2004 to 2018, we 
(a) Distribution of Argo Profiles

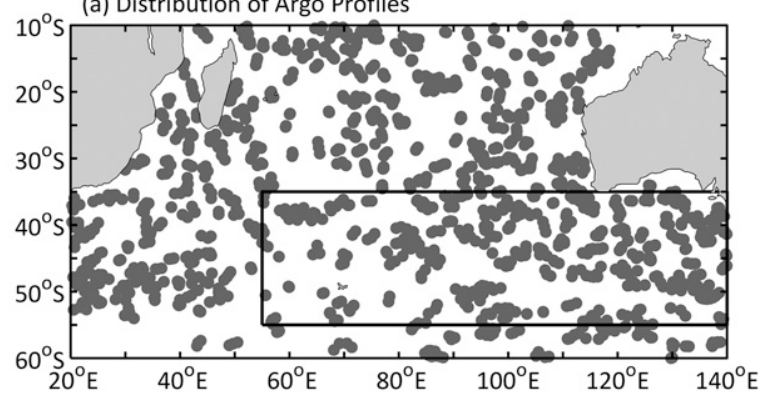

(b) Number of Argo Profiles

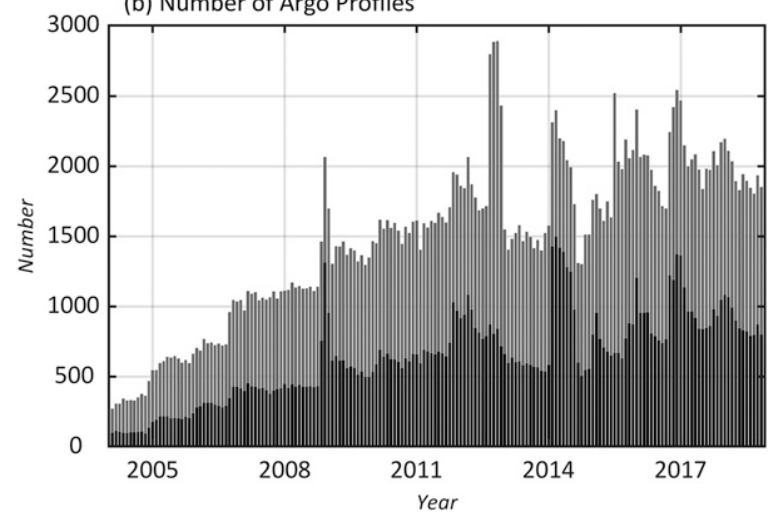

FIG. 1. (a) Distribution of Argo profiling floats in December 2018. (b) Monthly number of Argo profiling floats in the domain $20^{\circ}-140^{\circ} \mathrm{E}$ and $10^{\circ}-60^{\circ} \mathrm{S}$ (gray bars) and in the SAMW formation region [black box in (a), black bars].

use the monthly gridded fields from the Roemmich-Gilson Argo Climatology (RG Argo; Roemmich and Gilson 2009) in this study. These monthly fields have a regular $1^{\circ}$ horizontal resolution and 58 vertical levels in the upper $2000 \mathrm{~m}$. The Argo profiling floats are distributed throughout the SIO, and the cumulative number of floats has increased from less than 500 in the early period of the program to more than 1000 per month after 2006 (Fig. 1), providing a unique opportunity to detect the SAMW low-frequency variability in the SIO.

Both the Global Precipitation Climatology Project (GPCP; Adler et al. 2016) version 2.3 combined monthly precipitation dataset and the Objectively Analyzed Air-Sea Fluxes (OAFlux; Yu et al. 2008) monthly evaporation dataset are used to assess surface freshwater flux. Monthly surface heat flux and surface wind datasets are provided by the fifth-generation ECMWF atmospheric reanalysis (ERA5) of the global climate. The data for the period 2004-18 is used in this study.

\section{b. Method}

\section{1) Potential VORTiCity}

Mode water refers to a thick layer of water with homogeneous physical properties covering a large area of the ocean. Thus, mode water is featured with low potential vorticity (PV), which stands out from the surrounding water masses as a PV minimum. PV provides an excellent tracer for mode waters due to its conservative nature (McCartney 1982). PV is given by

$$
\mathrm{PV}=\frac{(f+\xi)}{\rho} \frac{\partial \sigma_{\theta}}{\partial z}
$$

where $f$ is the Coriolis parameter, as the planetary vorticity, $\xi$ is the relative vorticity, and $\rho=\sigma_{\theta}+1000 \mathrm{~kg} \mathrm{~m}^{-3}$ the potential density. The relative vorticity is usually negligible compared to the planetary vorticity. The PV values that define the boundaries of specific mode waters in the literature are generally obtained empirically from observations. Here, the SAMW is defined as the layer of low PV $\left(<0.5 \times 10^{-10} \mathrm{~m}^{-1} \mathrm{~s}^{-1}\right)$ formed deeper than 200 dbar but lighter than $\sigma_{\theta}=27.1 \mathrm{~kg} \mathrm{~m}^{-3}$ (Banks et al. 2002; Wong 2005).

\section{2) GeOstrophiC STREAMFUNCTION (ACCELERATION POTENTIAL)}

Geostrophic circulation transporting the SAMW from its formation regions is analyzed along isopycnal surfaces using a Montgomery geostrophic streamfunction (McDougall 1989; Montgomery 1937). The geostrophic streamfunction in isopycnal surfaces is expressed as

$$
A=\varnothing_{a}+p \delta=p_{0} \delta_{0}+\int_{\delta_{0}}^{\delta} p d \delta, \varnothing_{a}=\int_{p}^{p_{0}} \delta d p
$$

where $p$ is pressure, $\delta$ is specific volume anomaly, $p_{0}$ is reference pressure, and $\delta_{0}$ is specific volume anomaly at the reference pressure.

\section{3) BUOYANCY CONTRIBUTION TO SUBDUCTION}

Air-sea buoyancy forcing is an essential driver of the winter deep mixed layer via convection (Downes et al. 2010). The net surface buoyancy input is given by

$$
B_{\mathrm{net}}=\frac{g \alpha}{C_{p}} Q_{\mathrm{net}}-g \beta \rho_{0} S_{m}(E-P)-\frac{g}{\rho_{0} f} \mathbf{k} \times \boldsymbol{\tau} \cdot \nabla \rho_{m},
$$

where a positive (negative) $B_{\text {net }}$ indicates buoyancy gain (loss) that makes the surface density lighter (denser). The first term of the right-hand side represents the air-sea heat fluxes ( $Q_{\text {net }}$ is the sum of shortwave and longwave radiative and latent and sensible heat fluxes). The second term is the surface freshwater fluxes (evaporation minus precipitation, $E-$ $P)$. The third term is the Ekman transport acting on the mixed layer density gradient, denoting Ekman-transport heat and freshwater fluxes. The variable $g$ is the gravitational force, $C_{p}$ is the heat capacity of water, $\rho_{0}$ is the reference surface density, $S_{m}$ is the mixed layer salinity, $f$ is the Coriolis parameter, $\alpha$ is the thermal expansion coefficient, and $\beta$ is the haline contraction coefficient. The relative contribution of the surface heat and freshwater fluxes and the Ekman transport of heat and freshwater can be obtained based on the equation, as the kinematic definition of subduction is linked with the thermodynamics of the mixed layer (Downes et al. 2010; Marshall and Marshall 1995; Nurser and Marshall 1991). Here, the mixed layer depth (MLD) is defined as the depth where potential density differs from the 10 -m value by $0.03 \mathrm{~kg} \mathrm{~m}^{-3}$, which is considered as the optimal measure of the MLD in the Southern Ocean (de Boyer Montégut et al. 2004; Sallée et al. 2006). 


\section{4) Net ANNUAL MEAN SUbDUCTION RATE}

A kinematic approach for diagnosing subduction rate proposed by Marshall et al. (1993) is used in this study to quantify the formation rate of the SAMW. The net annual subduction rate $\left(S_{\text {ann }}\right)$ is defined as follows:

$$
S_{\mathrm{ann}}=-\mathbf{u}_{H} \cdot \nabla H-w_{e},
$$

where $\mathbf{u}_{H}$ is the horizontal geostrophic velocity at the base of the mixed layer, $H$ is the depth of wintertime mixed layer base, $w_{e}=\operatorname{curl}\left(\tau / \rho_{0} f\right)$ is the vertical velocity controlled by the Ekman pumping. The first term $\mathbf{u}_{H} \cdot \nabla H$ is referred to as the lateral induction. The second is the vertical pumping. The positive subduction represents water irretrievably entering the thermocline layer from the mixed layer in late winter.

\section{5) HeAVING AND SPICINESS IN THE SUBSURFACE LAYERS}

The method proposed by Bindoff and McDougall (1994) is used to evaluate temperature and salinity changes of the SAMW in terms of heaving and spiciness contributions. The decomposition is formulated as

$$
\begin{aligned}
& \left.\frac{d \theta}{d t}\right|_{p}=\left.\frac{d \theta}{d t}\right|_{n}-\left.\frac{d p}{d t}\right|_{n} \frac{\partial \theta}{\partial p}+\text { Residual, } \\
& \left.\frac{d S}{d t}\right|_{p}=\left.\frac{d S}{d t}\right|_{n}-\left.\frac{d p}{d t}\right|_{n} \frac{\partial S}{\partial p}+\text { Residual, }
\end{aligned}
$$

where $\theta$ is potential temperature, $S$ is salinity, $p$ is pressure, and $t$ is time. The subscripts $p$ and $n$ denote that the derivative is along the constant pressure and the isopycnal surface, respectively. The terms $\partial \theta / \partial p$ and $\partial S / \partial p$ are the vertical gradient of climatological mean potential temperature and salinity during 2004-18, respectively. The terms on the left side of Eqs. (5) and (6) represent the potential temperature and salinity change at pressure surface $p$. The first term on the right-hand side of Eqs. (5) and (6) is referred to as the "spiciness" term, a change in temperature or salinity on a fixed isopycnal surface, and the second term is the "heaving" term, an Eulerian measure of the temperature or salinity change at a fixed depth.

\section{Results}

\section{a. Changes in $S A M W$ properties}

Over the past 15 years, the SIO has experienced a nearly uniform warming trend in the upper $200 \mathrm{~m}$, with the warming pattern extending to $800 \mathrm{~m}$ south of $30^{\circ} \mathrm{S}$ and north of $12^{\circ} \mathrm{S}$ (Fig. 2a). However, the zonally averaged trend of the upperocean salinity shows a less uniform structure, with freshening around $10^{\circ}-30^{\circ} \mathrm{S}$ and salinification on its equatorward and poleward sides (Fig. 2b). The salinity trend south of $12^{\circ} \mathrm{S}$ extends down to $800 \mathrm{~m}$. These changes in temperature and salinity in the SIO might be tightly linked to the SAMW that occupies a large portion of the subsurface layer from the subtropics to midlatitudes, indicated by the climatological PV minimum (Figs. 2a,b).
The SAMW volume has undergone a significant reduction by up to $5.3 \times 10^{14} \mathrm{~m}^{3}(11 \%)$ during 2004-13, with only a slight increase after 2013 (Fig. 2c). Changes in the SAMW volume are closely related to changes in the SAMW thickness in the subtropical gyre (Figs. 2c,d), which might respond to changes in the subduction rate of the SAMW and thickness of the winter mixed layers in the Subantarctic Zone (Fig. 6; Downes et al. 2009; Hong et al. 2020).

As the impact of the SAMW volume variations on the volume-weighted mean potential temperature/salinity is not significant (not shown), results are discussed in terms of volume-weighted mean potential temperature/salinity anomalies with a climatological mean $\mathrm{PV}<0.5 \times 10^{-10} \mathrm{~m}^{-1} \mathrm{~s}^{-1}$ in the SIO. The volume-weighted mean potential temperature (salinity) shows significant variations during 2004-18, with negative (detrended) anomalies during 2006-10 (2007-11), positive (detrended) anomalies during 2011-15 (2012-16), and increasing linear trends of $1.1 \times 10^{-1}{ }^{\circ} \mathrm{C} \mathrm{decade}{ }^{-1}(0.5 \times$ $10^{-2}$ psu decade ${ }^{-1}$ ) during the entire period (Figs. 2e,f). The linear trend of the SAMW potential temperature over 2004-18 is significant, exceeding the $95 \%$ confidence level; however, the linear trend of salinity is nonsignificant. The difference between potential temperature and salinity variations might be related to the vertical distribution of the two parameters (Fig. S4 in the online supplemental material). The potential temperature within the SAMW layers decreases monotonically with pressure throughout the SIO, while the salinity within the SAMW layers decreases with pressure in the subtropical zone around $12^{\circ}-40^{\circ} \mathrm{S}$ but increases with pressure on its equatorward and poleward sides. The convergence of upper-ocean lowsalinity water above high-salinity water on the north and south sides of the subtropical zone is unfavorable for the salinification of the SAMW. The enhanced warm and freshwater transport into the tropical southeastern Indian Ocean by the Indonesian Throughflow (ITF) over the past decades hinders the salinification of the SAMW (Hu et al. 2019; Zhang et al. 2018). The changes in the SAMW properties are well captured by the EN4.2 reanalysis (Fig. S1 in the supplemental material). The climatological mean potential temperature and salinity of the SAMW is $10.1^{\circ} \mathrm{C}$ and $34.8 \mathrm{psu}$, respectively, close to earlier estimates from Banks et al. (2002) of $10.5^{\circ} \mathrm{C}$ and 34.9 psu for the PV minimum waters of $<0.6 \times 10^{-10} \mathrm{~m}^{-1} \mathrm{~s}^{-1}$. The interannual-to-decadal variation in potential temperature of the SAMW is less remarkable than the 15-yr linear trend, with its standard deviation only accounting for $\sim 35 \%$ of the total variance (Fig. 2e and Table 1). On the other hand, the interannual-to-decadal variation of the SAMW salinity is more remarkable than the linear trend, with a much larger standard deviation that accounts for $\sim 92 \%$ of the total variance (Fig. 2f and Table 1 ).

Changes in the SAMW properties are not uniform across different density layers. A two-layer structure with an upperlayer volume gain and a lower-layer volume loss is found in the SAMW during 2004-18, consistent with changes in the SAMW thickness (Figs. 3a,b). This implies that more L-SAMW $\left(\sigma_{\theta}<\right.$ $\left.26.7 \mathrm{~kg} \mathrm{~m}^{-3}\right)$ but less D-SAMW $\left(\sigma_{\theta}>26.8 \mathrm{~kg} \mathrm{~m}^{-3}\right)$ are formed during this period (Hong et al. 2020; Portela et al. 2020). As a consequence, opposite trends in heat and freshwater storage are exhibited in the two-layer structure, with an increasing 
(a) $\theta$ Trend [60-120E]

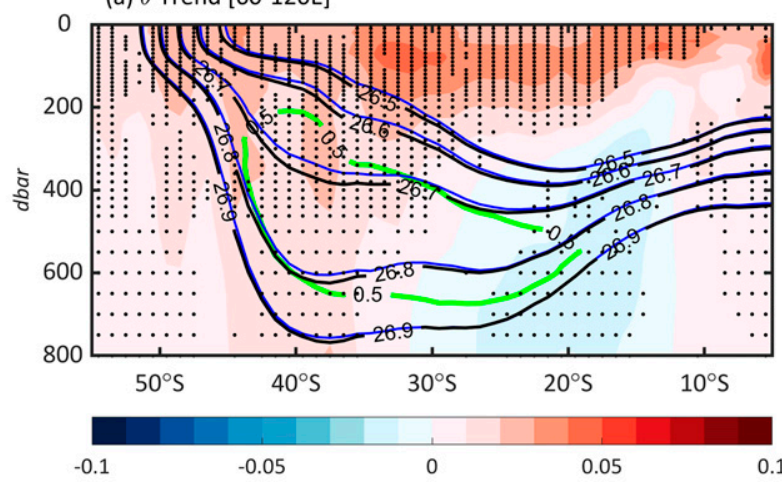

(c) V Ano

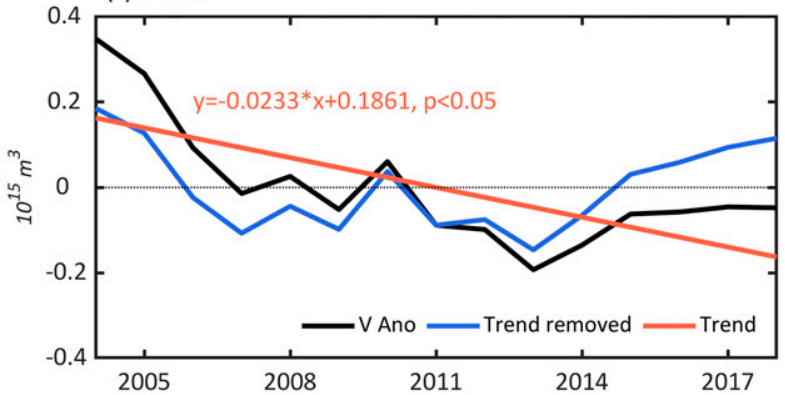

(e) $\theta$ Ano

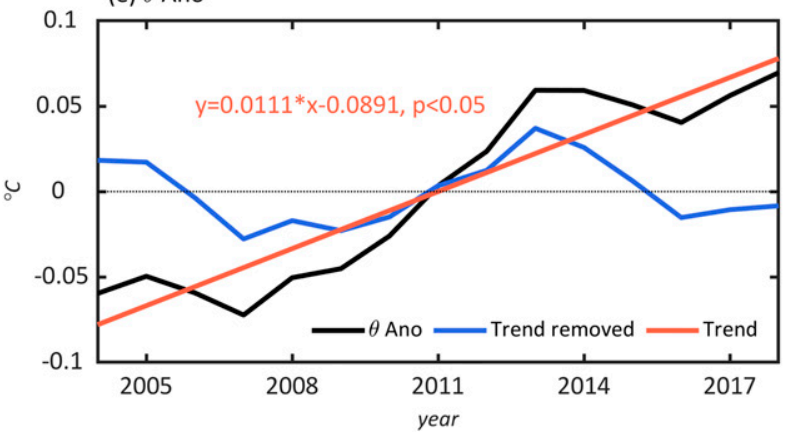

(b) Salinity Trend [60-120E]

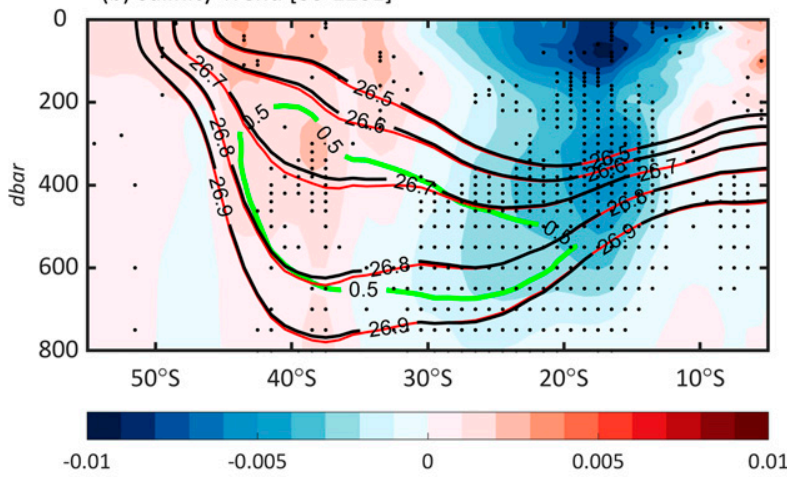

(d) Thickness Ano

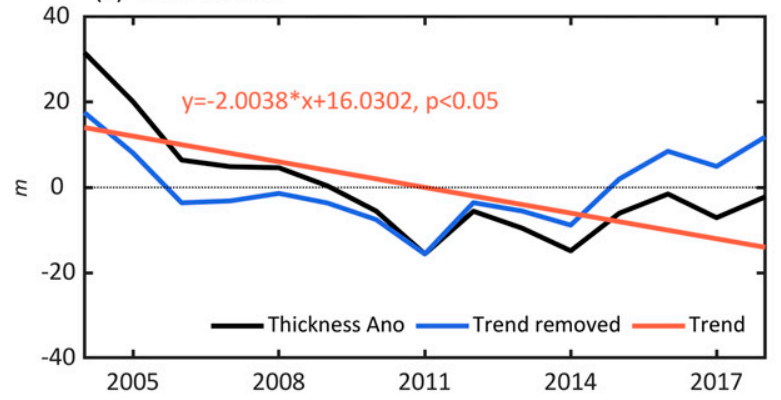

(f) S Ano

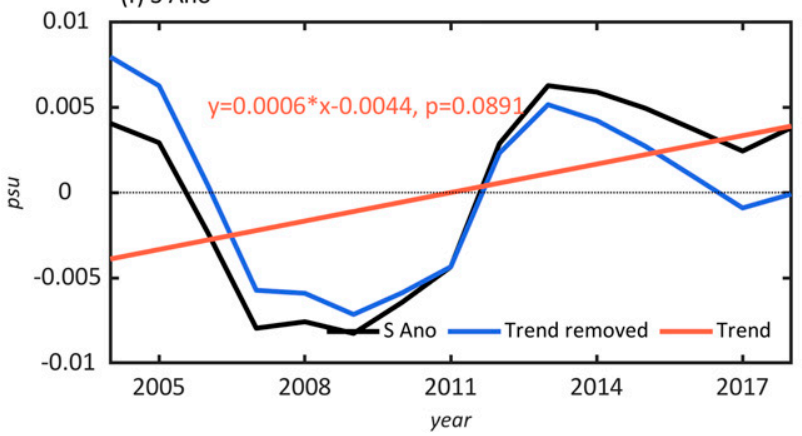

FIG. 2. Linear trends of zonally averaged $\left(60^{\circ}-120^{\circ} \mathrm{E}\right)$ (a) potential temperature $\left({ }^{\circ} \mathrm{C} \mathrm{yr}^{-1}\right.$; shaded) and (b) salinity (psu yr ${ }^{-1}$; shaded) for 2004-18, superimposed with the climatological mean potential density ( $\mathrm{kg} \mathrm{m}^{-3}$; black contours) and PV $\left(10^{-10} \mathrm{~m}^{-1} \mathrm{~s}^{-1}\right.$; enclosed green contours). Blue contours in (a) and red contours in (b) show potential density averaged during 2004-09 and 2010-15, respectively. The dotted areas in (a) and (b) indicate that linear trends are statistically significant at the $95 \%$ confidence levels from a modified MannKendall test. Annual mean, interannual to decadal variability, and linear trend of (c) volume, (d) thickness at $32.5^{\circ} \mathrm{S}$, (e) potential temperature, and (f) salinity anomalies of the SAMW. The $p<0.05$ means that the linear trends are statistically significant at the $95 \%$ confidence levels.

trend in the warm and salty L-SAMW and a decreasing trend in the cool and fresh D-SAMW (Figs. 3c,d), resulting in net increases of the volume-weighted mean potential temperature and salinity and therefore a net decrease in the potential density of the SAMW (Figs. 2e,f). The RG Argo results are consistent with that from the EN4.2 reanalysis data (Fig. S2).

Decomposition of the SAMW changes shows that both the heaving and spiciness processes are at work, with changes due to the 15-yr linear trend much larger than the interannualto-decadal variability (Fig. 4 and Table 1 ). In terms of interannualto-decadal variability, heaving contributes to the SAMW warming/salinification during 2008-2014 and cooling/freshening during the remaining period (Figs. 4b,d). The spiciness contribution is nearly out of phase from heaving (Figs. 4b,d). For the SAMW potential temperature, the interannual-todecadal variability of heaving only explains $26 \%$ of the total variance, while that of spiciness accounts for $48 \%$ of the total variance. Results for the SAMW salinity are similar, with interannual-to-decadal variability of heaving and spiciness processes accounting for $27 \%$ and $47 \%$ of the total variance, respectively.

For the 15-yr linear trend, heaving components for the decomposition of the SAMW potential temperature and salinity show increasing trends of $0.43^{\circ} \mathrm{C} \mathrm{decade}^{-1}$ and 0.06 psu decade $^{-1}$ 
TABLE 1. The standard deviation of total variations and interannual-to-decadal variations of volume-weighted mean potential temperature and salinity of the SAMW and corresponding heaving and spiciness processes.

\begin{tabular}{lcccccc}
\hline \hline & $\mathrm{STD}_{\theta}$ & $\mathrm{STD}_{\theta-H}$ & $\mathrm{STD}_{\theta-S}$ & $S T D_{S}$ & STD $_{S-H}$ & STD $_{S-S}$ \\
\hline Variations & 0.0522 & 0.1986 & 0.0786 & 0.0051 & 0.0256 & 0.0180 \\
Interannual-to-decadal variation & 0.0184 & 0.0522 & 0.0377 & 0.0047 & 0.0068 & 0.0084 \\
Percentage & $35 \%$ & $26 \%$ & $48 \%$ & $92 \%$ & $27 \%$ & $47 \%$ \\
\hline
\end{tabular}

at $95 \%$ confidence, respectively, which contribute to the warming and salinification of the SAMW; whereas the spiciness components experience decreasing trends of $-0.15^{\circ} \mathrm{C}$ decade ${ }^{-1}$ and -0.04 psu decade ${ }^{-1}$, respectively, which contribute to the cooling and freshening of the SAMW (Figs. 4a,c). Furthermore, the warming/salinification of the SAMW due to heaving is stronger than the cooling/freshening due to the spiciness process, resulting in a net warming/salinification trend in potential temperature/salinity (Figs. 4a,c). Similar results are found for the EN4.2 reanalysis data (Fig. S3).

Since the interannual-to-decadal variations in heaving and spiciness are comparatively smaller, in the following sections, we focus on the 15-yr linear trends of the SAMW potential temperature and salinity emerging from changes in heaving and spiciness.

\section{b. Vertical migration of isopycnals: Heaving}

The heaving contribution to warming/salinification of the SAMW (Figs. 4a,c) manifests as a deepening of isopycnal surfaces in the subtropical SIO during 2004-18, especially at $\sigma_{\theta}=26.5-26.9 \mathrm{~kg} \mathrm{~m}^{-3}$ (Fig. 5). Significant strengthening of wind stress and its curl takes place over the Subantarctic Zone during 2004-18, which contributes to the deepening of isopycnals not only by the enhanced Ekman pumping, but also by strengthened subtropical gyres and meridional overturning circulation (Liu et al. 2018; Qu et al. 2019). The strengthening of wind stress over the SAMW formation region is closely related to the poleward shift of the zero line of wind stress curl (Fig. S5), associated with an increasing southern annular mode (Lee et al. 2019; Lovenduski 2005). Moreover, the surface buoyancy flux over the SAMW subduction region shows a decreasing linear trend during 2004-18, which indicates a buoyancy loss of the ocean that favors a deepening MLD (Figs. 5e,f). Surface buoyancy fluxes are predominantly driven by air-sea heat flux (Fig. S6).

The depth of $\sigma_{\theta}=26.5-26.9 \mathrm{~kg} \mathrm{~m}^{-3}$ isopycnal surfaces in the subtropical SIO show a spatially uneven deepening trend, with a maximum rate of up to $50 \mathrm{~m}$ decade $^{-1}$. The largest deepening of the light isopycnal surfaces $\left(\sigma_{\theta} \leq 26.7 \mathrm{~kg} \mathrm{~m}^{-3}\right)$ is located in the central SIO, while that of the dense isopycnal surfaces $\left(\sigma_{\theta} \geq 26.8 \mathrm{~kg} \mathrm{~m}^{-3}\right)$ in the eastern SIO, showing good correspondence to the formation regions of those different SAMW classes. The deepening weakens gradually as the subducted water spreads northwestward in the interior ocean. Furthermore, the deepening of the $\sigma_{\theta}=26.5-26.9 \mathrm{~kg} \mathrm{~m}^{-3}$ (a) Volume Ano

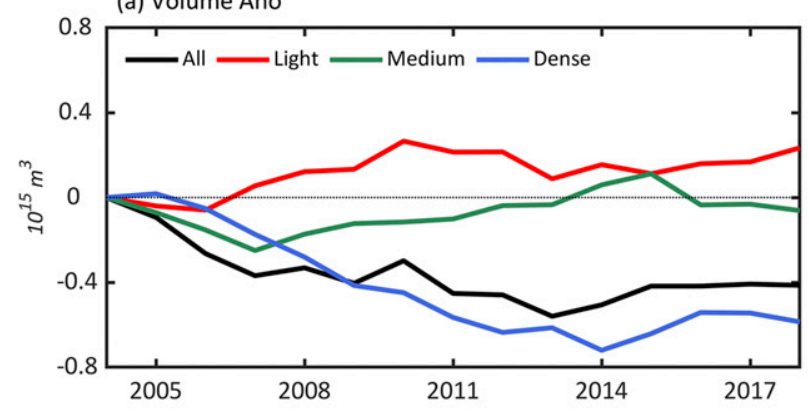

(c) OHC Ano

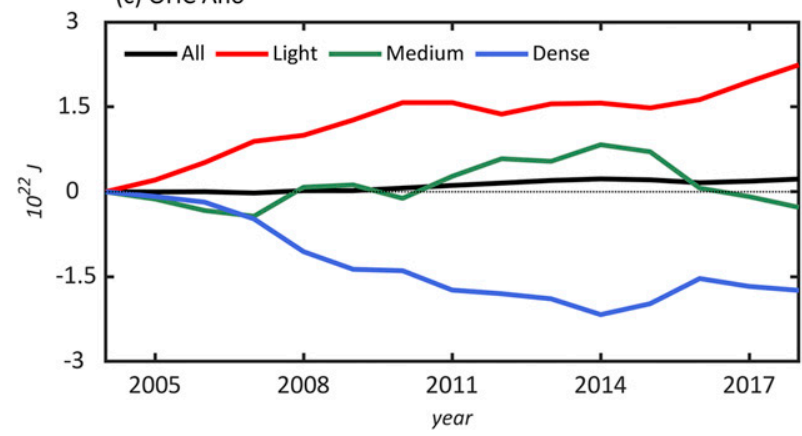

(b) Thickness Ano

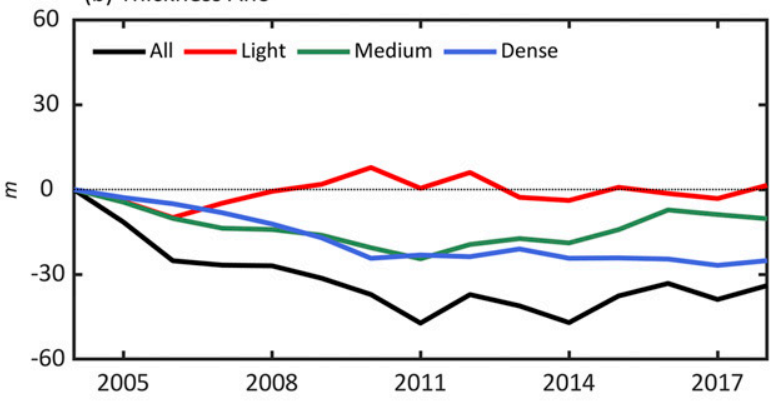

(d) OSC Ano



FIG. 3. Annual mean (a) volume, (b) thickness at $32.5^{\circ} \mathrm{S}$, (c) ocean heat content, and (d) ocean salinity content between different isopycnal layers of the SAMW. Light, medium, and dense means L-SAMW, M-SAMW, and D-SAMW, respectively. 
(a) $\theta$ Ano \& Heaving-Spiciness

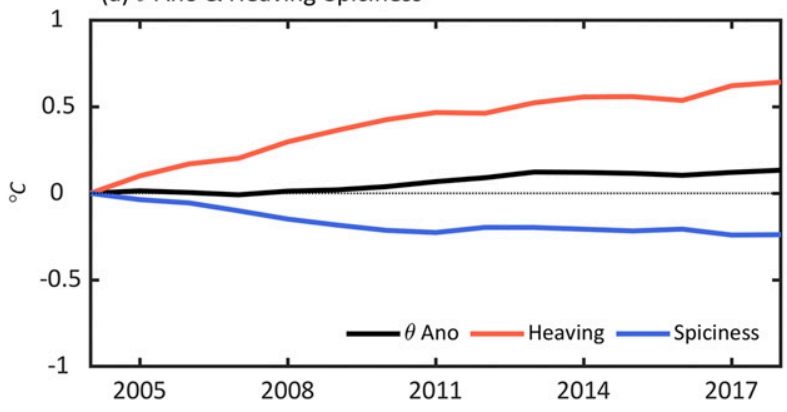

(c) S Ano \& Heaving-Spiciness

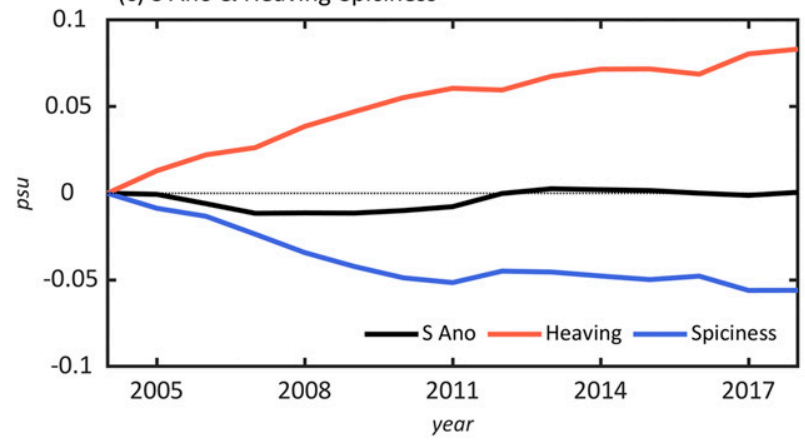

(b) Trend Removed

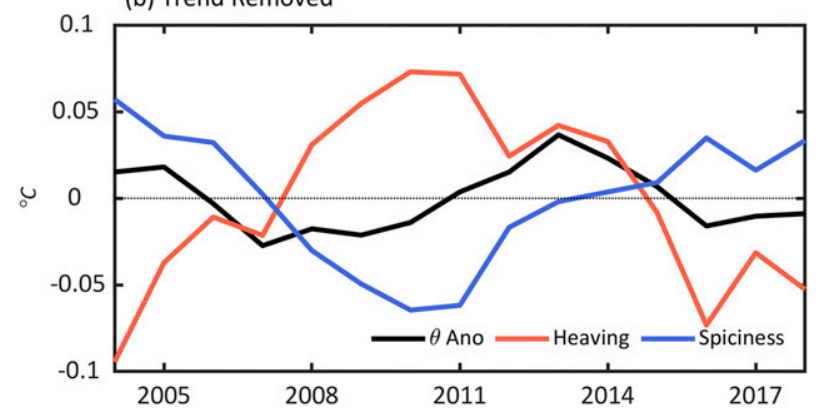

(d) Trend Removed

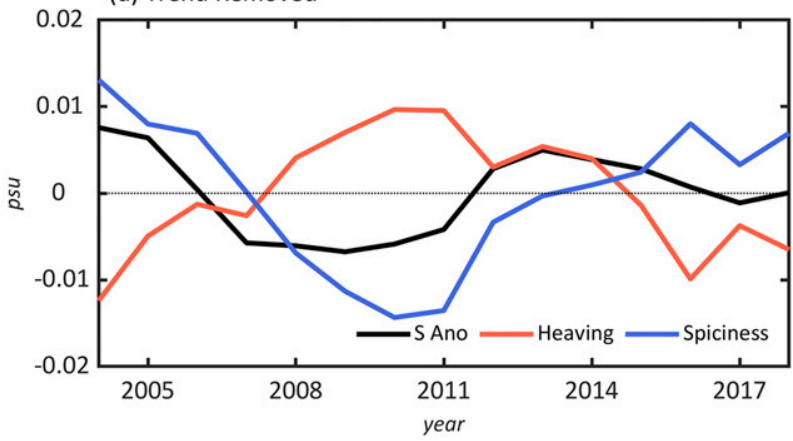

FIG. 4. Contribution of heaving and spiciness processes to changes in the SAMW (a),(b) potential temperature and (c),(d) salinity. Trends are removed in (b) and (d).

isopycnal surfaces is not uniform, with its maximum occurring within the M-SAMW $\left(\sigma_{\theta}=26.7-26.8 \mathrm{~kg} \mathrm{~m}^{-3}\right.$, Fig. 5). This result implies that more warm and salty SAMW, but less cool and fresh SAMW, enters the ocean interior via subduction and spreading laterally from its formation regions (Figs. 3c,d and 5), consistent with previous studies (Gao et al. 2018; Häkkinen et al. 2016; Qu et al. 2020). This, in turn, explains the observed two-layer structure of the SAMW, with volume gain in the upper layers and volume loss in the lower layers.

The subduction rate of the SAMW shows a large spatial variability with multipolar structures of hot spots within the winter deep mixed layers (Fig. 6a). These subduction rates $\left(400 \mathrm{~m} \mathrm{yr}^{-1}\right)$ are dominated by lateral induction, while contribution from vertical pumping is relatively weak (Figs. 6c,e). Similar multipolar structures are found in the trend of subduction rate during 2004-18 (Fig. 6b), in which lateral induction seems to play a dominant role (Figs. 6b,d,e). The climatological mean of the SAMW subduction rate is estimated to be $21 \mathrm{~Sv}$, in agreement with previous studies (Marsh et al. 2000b). A decreasing trend in the SAMW subduction rate is identified during 2004-18, especially before 2013. This decreasing trend is primarily responsible for the observed decrease in the SAMW volume. Most of the decreasing trend in the SAMW subduction rate is due to lateral induction (Fig. 6g), which in turn is dominated by changes in the MLD (Fig. 6h and Fig. S7). An increasing trend of the L-SAMW subduction rate and a decreasing trend of the D-SAMW subduction rate are found, which support the two-layer structure of the SAMW volume gain in the upper layers and volume loss in the lower layers (Fig. S7).
Changes in the MLD are largely controlled by changes in wind stress and surface buoyancy fluxes (Karstensen and Quadfasel 2002b; Sallée et al. 2010a). A convergence (divergence) of Ekman transport or a downward (upward) Ekman pumping (suction) over the SAMW subduction region can drive a deeper (shallower) MLD and consequently a larger (small) subduction. A buoyancy loss (gain) can deepen (shallow) the MLD by stronger (weaker) convection. Here, we examine changes in the MLD, wind tress, and surface buoyancy fluxes over the SAMW subduction regions where the winter MLD is deeper than $150 \mathrm{~m}$. Variability of the MLD in the subduction regions of different SAMW classes has its own characteristics (Fig. 7). In the L-SAMW subduction region, the MLD shows a quasi-biennial variation (Qu et al. 2020), highly related to buoyancy forcing rather than wind forcing. The MLD also shows a deepening trend during 2004-18, corresponding to a weakened surface buoyancy flux. In the M-SAMW and D-SAMW subduction regions, both buoyancy and wind forcing contribute to the MLD variability. In the D-SAMW subduction region, long-lasting negative MLD anomalies occur during 2007-14 (Fig. 7f), responsible for the reduction in the D-SAMW subduction rate and volume (Hong et al. 2020). In addition, the diapycnal transformation from the D-SAMW to the Antarctic Intermediate Waters might also contribute to the D-SAMW volume loss (Portela et al. 2020).

\section{c. Temperature/salinity changes at isopycnals: Spiciness}

The spiciness contribution to the cooling/freshening of the SAMW is mainly driven by density-compensated changes in 
(a) Press Trend $\sigma_{\theta}=26.5 \mathrm{~kg} / \mathrm{m}^{3}$

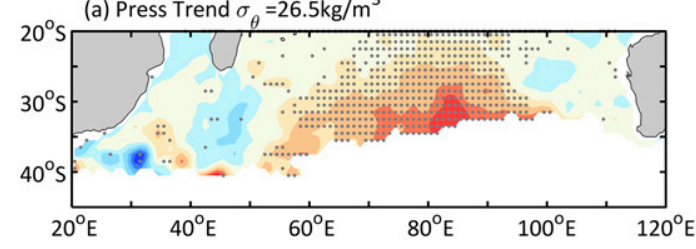

(c) Press Trend $\sigma_{\theta}=26.7 \mathrm{~kg} / \mathrm{m}^{3}$

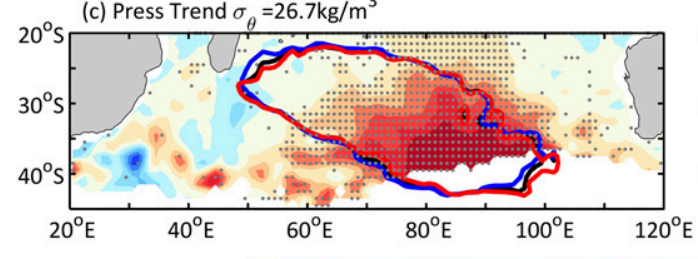

(b) Press Trend $\sigma_{\theta}=26.6 \mathrm{~kg} / \mathrm{m}^{3}$



(d) Press Trend $\sigma_{\theta}=26.8 \mathrm{~kg} / \mathrm{m}^{3}$

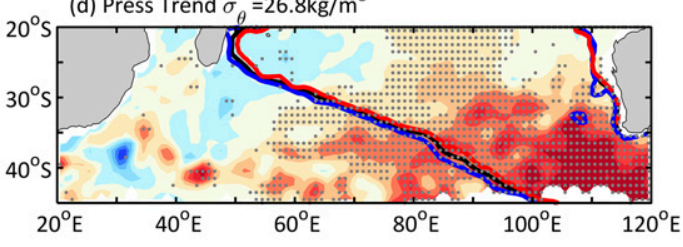

(e) Bf Trend

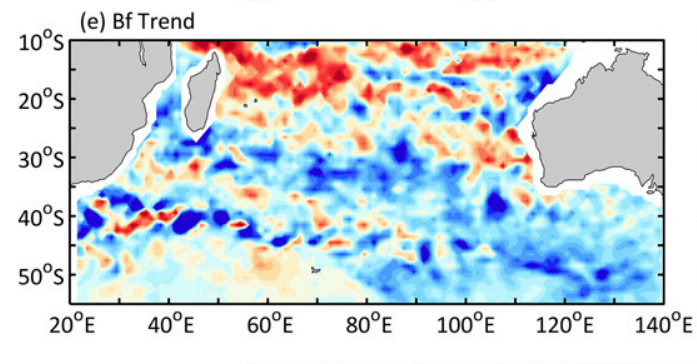

$0 \quad 30 \quad 60$

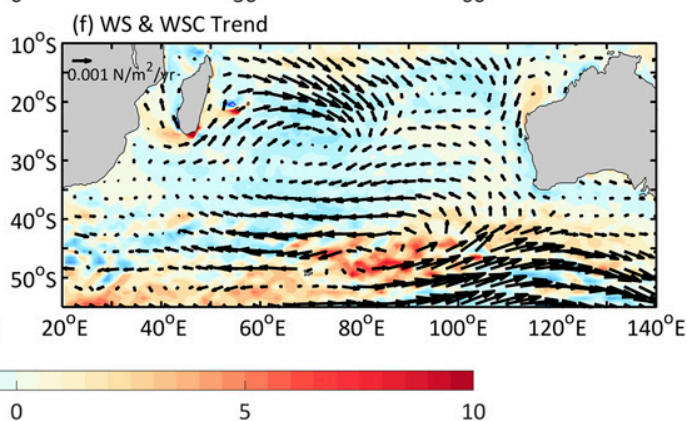

$-10$

$-5$

10

FIG. 5. (a)-(d) Linear trends of pressure $\left(\mathrm{dbar} \mathrm{decade}^{-1}\right)$ of the $\sigma_{\theta}=26.5-26.8 \mathrm{~kg} \mathrm{~m}^{-3}$ isopycnal surfaces during 2004-18, superimposed with annual-mean low PV (contours). The black contour represents the mean value averaged over 2004-18, and the blue (red) contour is the mean value averaged during 2004-09 (2013-18). The dots indicate the area where the fitted linear trend is above the $95 \%$ confidence level. Linear trend of (e) surface buoyancy flux $\left(10^{-7} \mathrm{~kg} \mathrm{~m}^{-1} \mathrm{~s}^{-3} \mathrm{yr}^{-1}\right.$; shaded), and (f) wind stress $\left(\mathrm{N} \mathrm{m}^{-2} \mathrm{yr}^{-1}\right.$; vectors) and wind stress curl $\left(10^{-9} \mathrm{~N} \mathrm{~m}^{-3} \mathrm{yr}^{-1}\right.$; shaded) during 2004-18.

the winter mixed layer properties in the SAMW formation region, as explained below. The irreversible transfer of water mass from the mixed layer into the ocean interior occurs within a short time scale of only 1-2 months. On the other hand, it takes more than 3 years for the spiciness signals to spread into the interior of the subtropical ocean (Fine et al. 2008; Karstensen and Tomczak 1998; Koch-Larrouy et al. 2010). In addition to isopycnal advection, diapycnal mixing and diffusion can also cause spiciness changes, which tend to increase temperature and salinity by downward velocity in the thermocline of the SIO (You 1996). However, decreases rather than increases in temperature and salinity occur in the isopycnal surfaces. Therefore, diapycnal mixing and diffusion are not considered here as major driving factors. Considering the 3-yr delay, we compare the winter mixed layer properties during 2010-15 with those during 2004-09 to explain changes in the interior ocean during 2004-18.

Increases in the mixed layer temperature and salinity averaged between July and September (JAS) are found in the SAMW formation region (Figs. 8a,b); however, the spiciness in the interior ocean shows cooling/freshening trends during 2004-18 at 95\% confidence (Figs. 4a,c and 12). Indeed, changes in the mixed layer alter the potential density as well as the temperature and salinity of the subducted water along isopycnals.

The increase in temperature overwhelms the salinity effect and therefore reduces local density, causing a southward displacement of the outcropping lines for the density surfaces between 26.5 and $26.8 \mathrm{~kg} \mathrm{~m}^{-3}$ (Fig. 8). The outcropping lines averaged over the SAMW formation region move southward by more than $1^{\circ}$ latitude, with temperature and salinity decreasing by up to $0.6^{\circ} \mathrm{C}$ and $0.1 \mathrm{psu}$, respectively (Figs. $8 \mathrm{e}-\mathrm{g}$ ). This overwhelms the local increase of $0.4^{\circ} \mathrm{C}$ in temperature and $0.5 \times 10^{-1} \mathrm{psu}$ in salinity averaged over the SAMW formation region (Figs. 9c,f). The strong meridional gradients of mixed layer temperature and salinity are responsible for the decrease in mixed layer temperature and salinity, respectively (Figs. 8c,d). This poleward displacement of outcropping lines thus induces cooler and fresher water, rather than warmer and saltier water, to subduct into the permanent thermocline within the density range 26.5$26.8 \mathrm{~kg} \mathrm{~m}^{-3}$ (Figs. 8e,g). This density-compensated change is responsible for the cooling and freshening contribution of spiciness to the SAMW. Furthermore, the poleward displacement of outcropping lines causes the expansion of the L-SAMW formation region and the shrinking of the 



FIG. 6. Climatological mean $\left(\mathrm{m} \mathrm{yr}^{-1}\right)$ and linear trend $\left(\mathrm{m} \mathrm{yr}^{-2}\right)$ of (a),(b) annual subduction rate, (c),(d) lateral induction term, and (e),(f) vertical pumping term during 2004-18. (g),(h) Time series of annual mean subduction rate, lateral induction term, and vertical pumping term averaged within the mixed layer density range of $26.5-27.1 \mathrm{~kg} \mathrm{~m}^{-3}$. The labels " $\mathrm{u} * \nabla H$," "um $* \nabla H$," and " $\mathrm{u} * \nabla H \mathrm{Hm}$ " in (h) represent lateral induction with temporally geostrophic current and mixed layer depth, lateral induction with climatological geostrophic current and temporally varying mixed layer depth, and lateral induction with climatological mixed layer depth and temporally varying geostrophic current, respectively.

D-SAMW formation region, leading to a two-layer structure of the SAMW.

Although the subducted water becomes cooler and fresher, the volume of warm and salty L-SAMW increases and the volume of cool and fresh D-SAMW decreases, resulting in a net gain of the volume-weighted potential temperature and salinity of the SAMW.

\section{d. Changes in the mixed layer}

In the SAMW formation region, air-sea fluxes and equatorward Ekman transport are the main drivers of property changes in the winter mixed layer (Dong et al. 2007; Rintoul and England 2002; Sallée et al. 2006). Thus, the contribution of air-sea fluxes and Ekman transport to changes in winter mixed layer temperature and salinity in the SAMW formation region where the winter MLD is deeper than $150 \mathrm{~m}$ needs to be assessed (Fig. 9). A negative (positive) value in budget results indicates heat or salt loss (gain) from the SAMW formation region.

In the climate mean state, the annual average net air-sea heat flux of $-87.3 \mathrm{~W} \mathrm{~m}^{-2}$ represents a release of heat from the ocean to the atmosphere over the SAMW formation region (Fig. 9). The heat loss by air-sea heat flux is dominated by the longwave radiation $\left(-58.8 \mathrm{~W} \mathrm{~m}^{-2}\right)$ and latent heat flux $\left(-105.3 \mathrm{~W} \mathrm{~m}^{-2}\right)$. The Ekman advection transports cooler water $\left(-25.9 \mathrm{~W} \mathrm{~m}^{-2}\right)$ from the south thus cools the mixed layer in the SAMW formation region. Both of these processes contribute to destabilizing the winter mixed layer via strong convective overturn. Compared with 2004-09, the increase in mixed layer temperature during 2010-15 is dominated by the weakened Ekman advection. The Ekman advection of heat decreases by around $13 \%$ from -28.0 

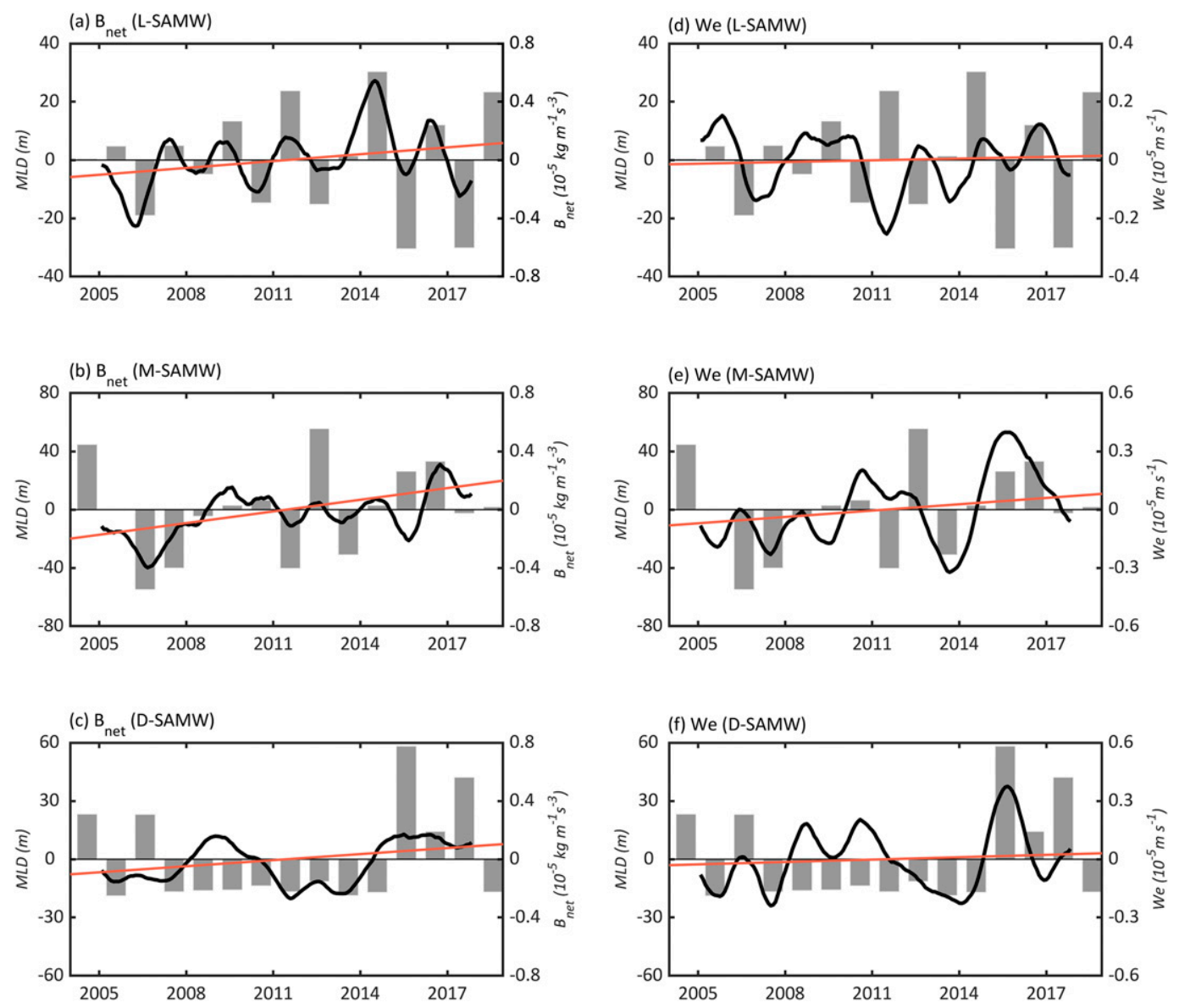

FIG. 7. Wintertime (JAS) mixed layer depth anomalies (bars) of (a)-(c) sea surface buoyance ( $-B_{\text {net }}$; positive means buoyancy loss, line), and (d)-(f) downward Ekman pumping velocity (line) averaged over the SAMW subduction regions $\left(55^{\circ}-140^{\circ} \mathrm{E}, 30^{\circ}-55^{\circ} \mathrm{S}\right)$ between different isopycnal layers. High-frequency signals are removed by applying a 13 -month running mean twice.

to $-24.5 \mathrm{~W} \mathrm{~m}^{-2}$ during $2010-15$ compared with $2004-09$, which is attributed to subdued northward transport of cool water to the SAMW formation region. The decrease in equatorward Ekman transport is driven by anomalous easterly winds south of $45^{\circ} \mathrm{S}$ during 2010-15 compared with 2004-09 (Figs. 9 and 10). The net air-sea heat flux is positive (heat gain) in some areas southwest of Australia while a negative (heat loss) in most central SIO areas. The net airsea heat flux anomaly averaged over the mixed layer of the SAMW formation region during 2004-09 compared with that during 2010-15 is negative, which means more heat loss over the region of the deep mixed layer (Figs. 9 and 10). The strengthened latent heat flux is responsible for changing net air-sea heat flux (Fig. 9c).

For mixed layer salinity, the climatological mean Ekman advection transports fresher water $\left(-87.9\right.$ psu mm day $\left.^{-1}\right)$ from the south and contributes to the freshening of the mixed layer in the SAMW formation region. However, the precipitation $\left(-86.7\right.$ psu mm day $\left.{ }^{-1}\right)$ over the SAMW formation region is almost equivalent to the evaporation (105.3 psu mm day ${ }^{-1}$ ). Thus, the freshwater flux (evaporation minus precipitation,
$E-P)$ marginally increases the mixed layer salinity in the SAMW formation region. Compared with 2004-09, similar to the heat, the Ekman advection of freshwater decreases by around $14 \%$ from -95.7 to -82.5 psu mm day $^{-1}$ during $2010-$ 15 , contributing to the mixed layer salinity increase in the SAMW formation region (Figs. 9 and 10). In addition, changes in freshwater flux also contribute to the mixed layer's salinification during 2010-15, with reduced precipitation overwhelming weakened evaporation (Figs. 9 and 10). Thus, air-sea freshwater fluxes and Ekman freshwater advection dominate the increase in the mixed layer salinity. In contrast, the increase in the mixed layer temperature is driven by Ekman heat advection rather than air-sea heat fluxes.

\section{e. Relationship with the southern annular mode}

The southern annular mode (SAM), as a major driver of Southern Hemisphere variability, is featured by a seesaw pattern for atmospheric mass between the mid- and high latitudes of the Southern Hemisphere (Hartmann and Lo 1998; Thompson and Wallace 2000). The SAM is characterized by multiple time scales, with more frequent positive events 

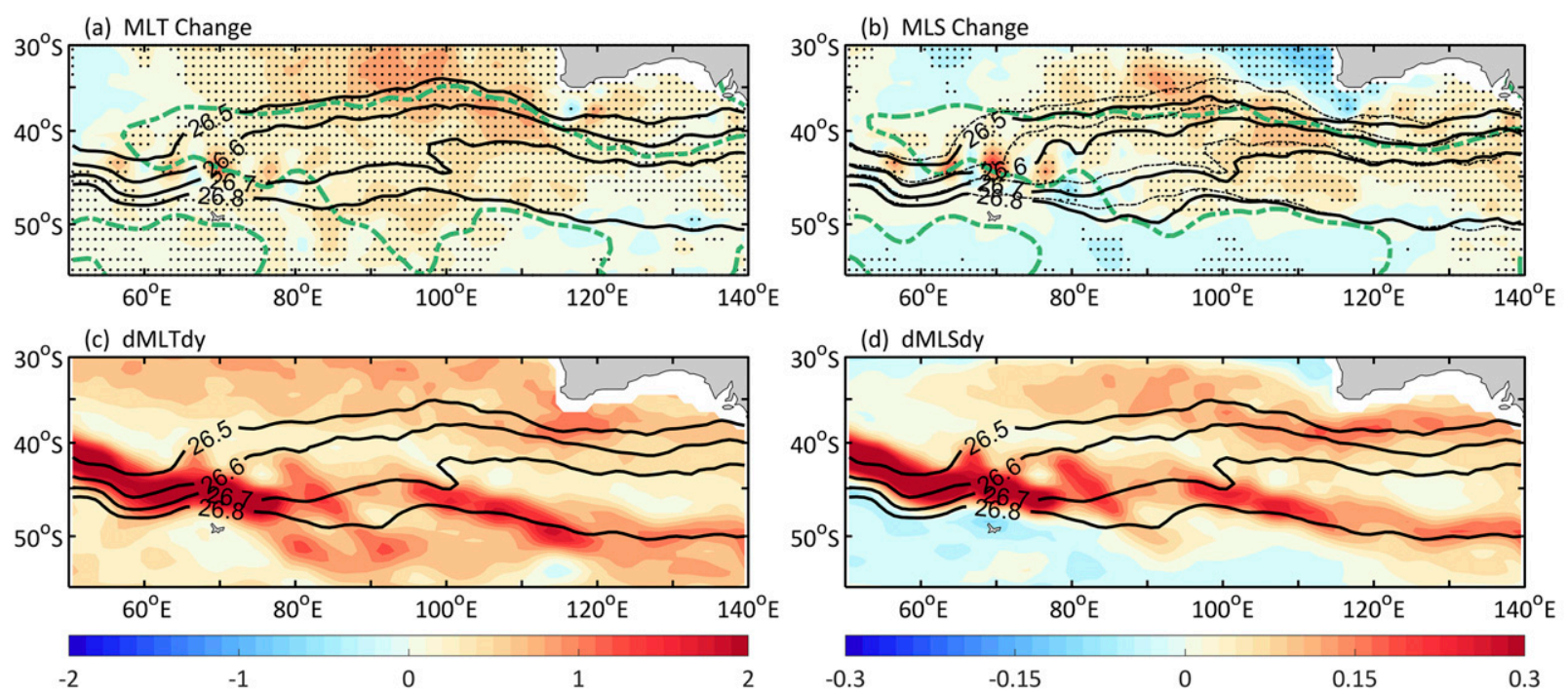

(e) Latitude Mean \& Change


FIG. 8. Wintertime (JAS) mixed layer (a) temperature $\left({ }^{\circ} \mathrm{C}\right.$; shaded) and (b) salinity (psu; shaded) differences between $2010-15$ and 2004-09, superimposed with climatological mean potential density (solid black lines) and mixed layer depth of $150 \mathrm{~m}$ (dashed green lines) during 2004-09 and 2010-15, respectively. Climatological mean mixed layer (c) temperature $\left({ }^{\circ} \mathrm{C}\right.$ ) and (d) salinity (psu) meridional gradients in JAS during 2004-2018. Wintertime (JAS) mixed layer (e) potential density latitude and corresponding (f) temperature and (g) salinity along longitude averaged during 2004-18 and their differences between 2010-15 and 2004-09.

in recent decades (Fig. S8). On the decadal to multidecadal time scales, the SAM is in positive phase during 2004-18 (Fig. 11a). North of $50^{\circ} \mathrm{S}$, the zonal wind stress weakens during the positive phase of SAM, as their correlation is negative. In contrast, the zonal wind stress south of $50^{\circ} \mathrm{S}$ strengthens during positive SAM, as their correlation turns positive (Fig. 11b). Thus, positive wind stress curl anomalies occur over $40^{\circ}-55^{\circ} \mathrm{S}$ (Fig. 11c), consistent with previous studies (Hall and Visbeck 2002; Lovenduski 2005; Marshall 2003; Yang et al. 2016). Furthermore, the meridional Ekman advection can be influenced by changes in SAM. The mixed layer temperature and salinity show a weak positive correlation with the SAM index at $95 \%$ confidence (Figs. 11d,e), which can explain, to a certain extent, the observed changes in the mixed layers. Positive correlations between the net air-sea and latent heat fluxes and the SAM index are found in the central SIO. In contrast, no significant correlation exists in most SAMW formation regions (Figs. 11f,g). The correlation between evaporation/ precipitation and the SAM index is negative, which means reduced evaporation and precipitation (Figs. 11h,i). This result is consistent with the changes in evaporation and precipitation during 2004-15.

ENSO might be another important driver of the SAMW variability in the SIO by affecting the air-sea interactions over the SAMW formation region (Sallée et al. 2008b). The impact of ENSO on the SAMW properties is not analyzed in this study, and we leave it for a future investigation.

\section{Spiciness variations in the permanent thermocline}

The SAMW subducts into the permanent thermocline and continues to spread through the gyre circulation. It retains the winter conditions of its formation region and efficiently transports temperature and salinity anomalies caused by airsea interactions. The anomalous temperature and salinity are mainly advected by the mean geostrophic current along the isopycnal surfaces (Luyten et al. 1983), which are temperaturesalinity compensated and referred to as spiciness anomalies. A significant cooling and freshening (spiciness) trend is found on the $\sigma_{\theta}=26.5-26.8 \mathrm{~kg} \mathrm{~m}^{-3}$ isopycnal surfaces during 2004-18, covering much of the SIO south of $10^{\circ} \mathrm{S}$. The most robust cooling and freshening trends reach up to $-0.4^{\circ} \mathrm{C}$ decade $^{-1}$ and -0.1 psu decade ${ }^{-1}$ at $95 \%$ confidence on the $\sigma_{\theta}=26.5-$ $26.8 \mathrm{~kg} \mathrm{~m}^{-3}$ isopycnal surfaces, respectively (Figs. 12a,b). This results in the subduction of cooler and fresher water due to poleward displacement of outcropping lines.

The pathways of spiciness anomalies are largely set by the subtropical gyre circulation in the SIO (Fig. 12). There are two 

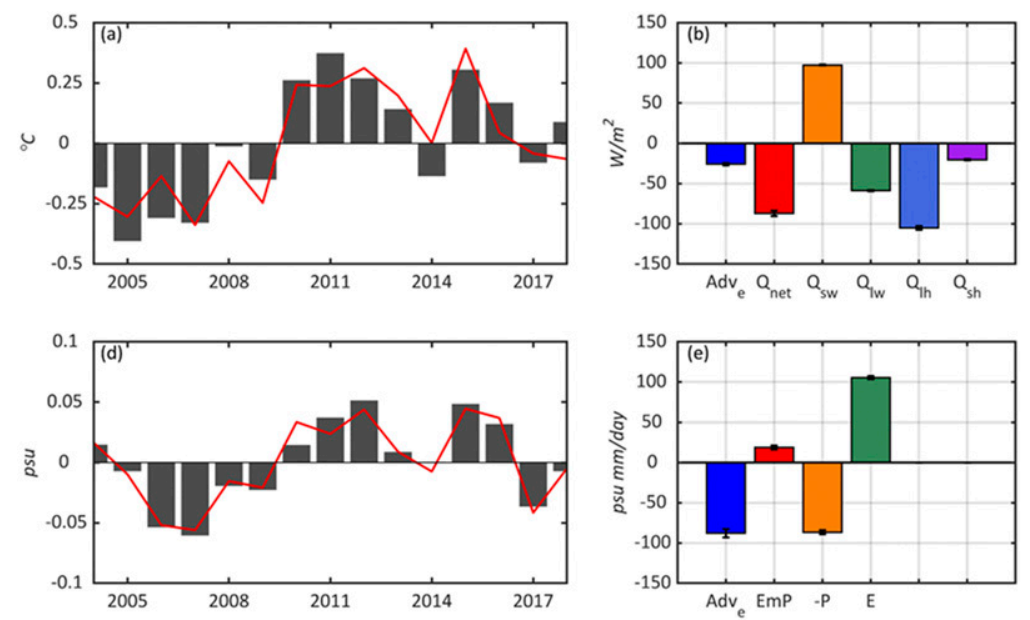
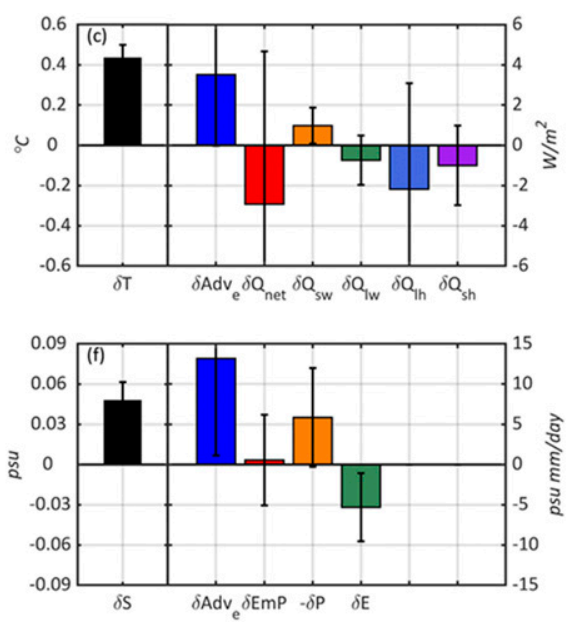

FIG. 9. Mixed layer variations in the SAMW formation region and contributions of air-sea fluxes and meridional Ekman heat/freshwater advection during winter (JAS). (a) Time series of mixed layer potential temperature, (b) climatological mean air-sea heat fluxes $\left[Q_{\mathrm{net}}=Q_{\mathrm{sw}}+Q_{\mathrm{lw}}+Q_{\mathrm{lh}}+Q_{\mathrm{sh}}\right.$ : net air-sea heat flux; $Q_{\mathrm{sw}}$ : shortwave radiation; $Q_{\mathrm{lw}}$ : longwave radiation; $Q_{\mathrm{lh}}$ : latent heat flux; $Q_{\mathrm{sh}}$ : sensible heat flux) and meridional Ekman heat advection $\left(\operatorname{Adv}_{e}=-\rho C_{p} V_{e}(d \mathrm{MLT} / d y)\right]$ and (c) their changes between 2010-15 and 2004-09. (d) Time series of mixed layer salinity, (e) climatological mean air-sea freshwater fluxes $\left[S_{0}(E-P) ; P\right.$ : precipitation; $E$ : evaporation] and meridional Ekman freshwater advection $\left[\mathrm{Adv}_{e}=-V_{e}(d \mathrm{MLS} / d y)\right]$ and (f) their changes between 2010-15 and 2004-09. Bars in (a) and (d) represent changes in winter (JAS), and lines represent yearly mean change. The error bars in (b), (c), (e), and (f) represent one standard error based on a Student's $t$ test.

distinct pathways for the spread of spiciness anomalies from the SAMW formation region. First, the spiciness anomalies of the SAMW generated off the southwest coast of Australia spread slowly northward to the tropics via the anticyclonic subtropical gyre and then rapidly westward by the South Equatorial Current (Fig. 12c), suggesting that the spiciness anomalies propagate at speed close to the mean current velocities (Kolodziejczyk et al. 2019). Second, the spiciness anomalies west of $100^{\circ} \mathrm{E}$ extend northwestward, toward the subtropical southwestern Indian Ocean, through the subtropical gyre (not shown). A positive spiciness signal occurs in the SAMW outcropping areas during 2004-09, while a negative spiciness signal takes place during 2010-15 (Fig. 12d). It takes around 3 years for these spiciness signals to spread into the interior of the subtropical ocean. Thus, a significant freshening/cooling trend on the $\sigma_{\theta}=26.5-26.8 \mathrm{~kg} \mathrm{~m}^{-3}$ isopycnal surfaces appear over much of the SIO during 2004-18 (Fig. 12). Moreover, the strengthening Indonesian Throughflow over the past decades might contribute to the cooling/freshening trend between $15^{\circ}$ and $20^{\circ} \mathrm{S}$ in the SIO (Hu et al. 2019; Li and Wang 2015;


FIG. 10. The change of (a) air-sea heat flux ( $\mathrm{W} \mathrm{m}^{-2}$; shaded), (b) wind stress $\left(\mathrm{N} \mathrm{m}^{-2}\right.$; vector) and Ekman heat advection ( $\mathrm{W} \mathrm{m}^{-2}$; shaded), (c) freshwater flux (psu mm day ${ }^{-1}$; shaded), and (d) zonal wind stress $\left(\mathrm{N} \mathrm{m}^{-2}\right.$; contour) and Ekman freshwater advection (psu mm day ${ }^{-1}$; shaded) averaged during July-September between 2004-09 and 2010-15. The green contour in (a)-(d) represents a winter deep mixed layer at a depth of $150 \mathrm{~m}$ averaged during 2004-18. The black contours in (a) and (c) are potential density averaged during 2004-18. 
(a) SAM Index
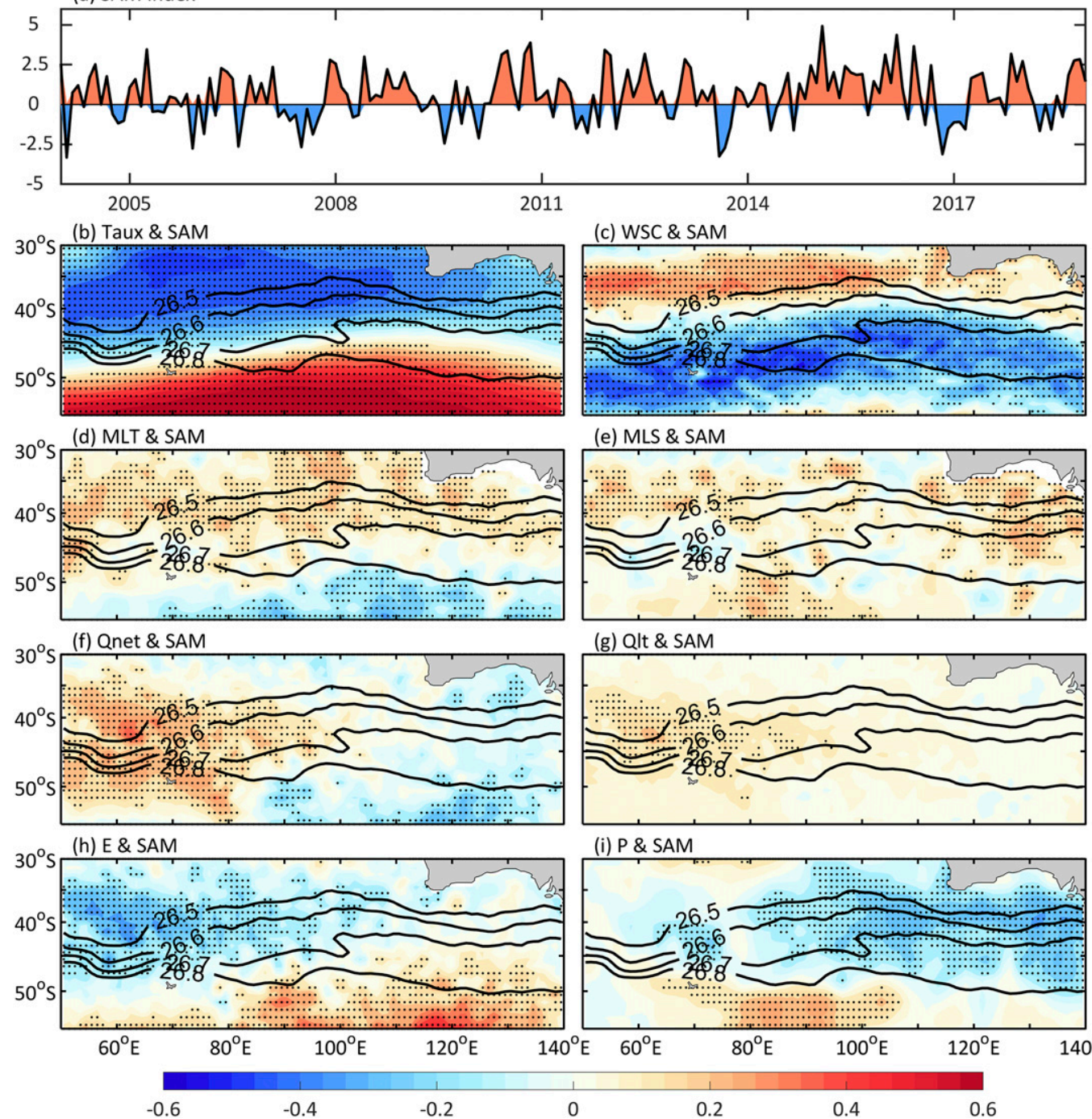

(i) P \& SAM

FIG. 11. (a) Time series of the SAM index. The mapped correlation coefficient of (b) zonal wind stress, (c) wind stress curl, (d) mixed layer temperature, (e) mixed layer salinity, (f) net air-sea heat flux, (g) latent heat flux, (h) evaporation, and (i) precipitation with the SAM index. The dots in (b)-(i) indicate the area where the fitted correlation is above the $95 \%$ confidence level.

Zhang et al. 2018). The enhanced circulation in the SIO (not shown) might also contribute to the spiciness anomalies when this anomalous current crosses the salinity front ( $\mathrm{Li}$ et al. 2012; Schneider 2000), which likely explains the uneven spatial distribution of the spiciness anomalies.

\section{Discussion}

The SAMW subduction rate is closely related to the deep winter mixed layers in the SAMW formation region. Air-sea buoyancy forcing and wind forcing are considered the two most important processes responsible for the formation of deep winter mixed layers in the Subantarctic Zone (Holte et al. 2012). Gao et al. (2018) point out that wind forcing rather than buoyancy forcing is responsible for increases in the depth and thickness of the SAMW over the Southern Hemisphere oceans during 200515 through stronger convective overturn. Qu et al. (2020) suggest that the deepening mixed layers and consequently the increasing SAMW subduction rate contribute to increasing the SAMW volume during 2005-19, as a result of strengthening westerly winds. However, Kolodziejczyk et al. (2019) imply that the Ekman pumping anomalies cannot explain the deepening of isopycnal surfaces and that the air-sea buoyancy flux anomalies may be the possible driving force during 2006-15. Hong et al. (2020) suggest that changes in both sea surface buoyancy flux and Ekman pumping contribute to the MLD changes over the SAMW formation region in the SIO during 2004-15. Thus, the relative importance of air-sea buoyancy flux and wind forcing varies with different periods and formation regions. 

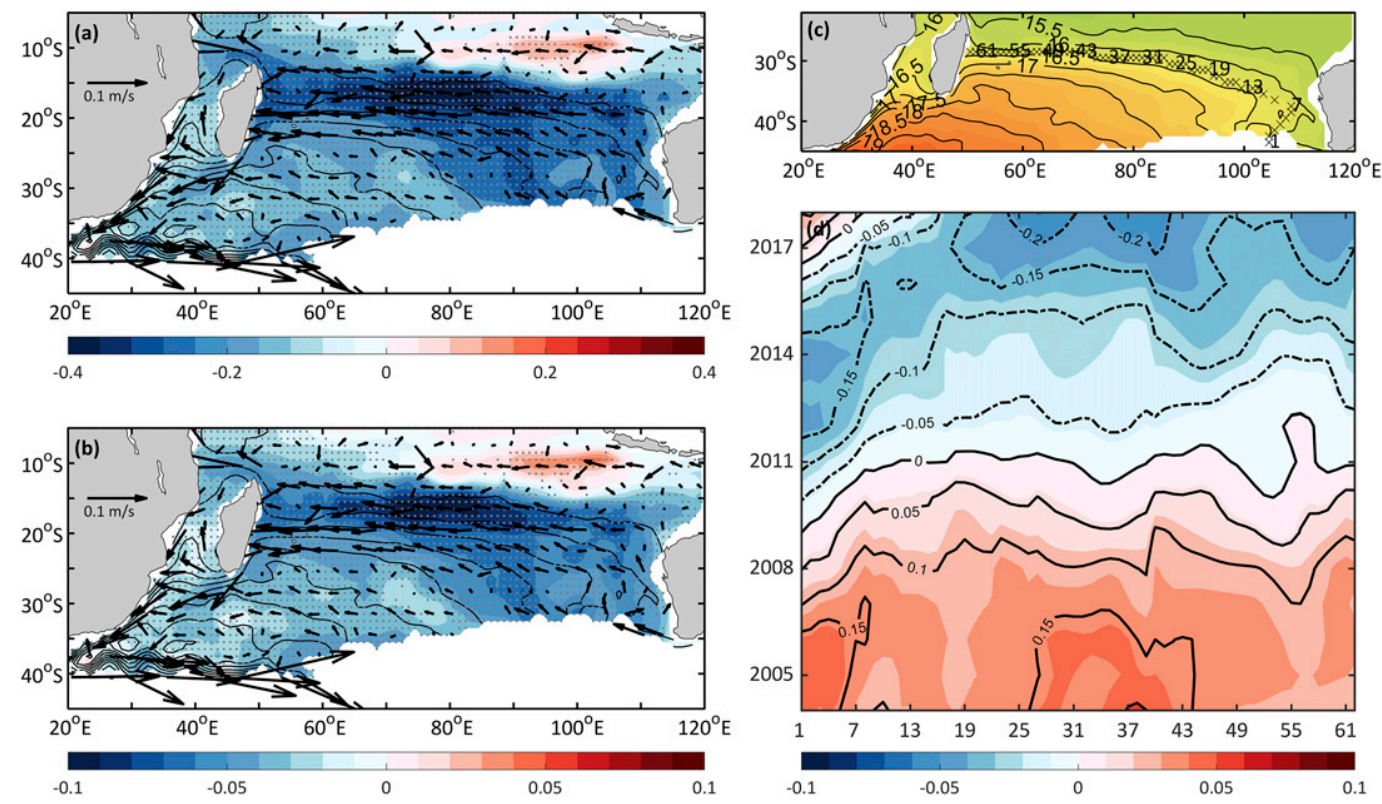

FIG. 12. The linear trend of Argo annual mean (a) potential temperature $\left({ }^{\circ} \mathrm{C}\right.$ decade ${ }^{-1}$; shaded) and (b) salinity (psu decade ${ }^{-1}$; shaded) and (b) salinity ( $\mathrm{psu} \mathrm{yr}^{-1}$; shaded) averaged on $\sigma_{\theta}=26.5-26.8 \mathrm{~kg} \mathrm{~m}^{-3}$ isopycnal surfaces during 2004-18, superimposed with annual mean streamlines (contours) and geostrophic currents (vectors). (c) Annual-mean streamlines (acceleration potential) for mean current averaged on $26.6-26.8 \mathrm{~kg} \mathrm{~m}^{-3}$ isopycnal surfaces from 2004 to 2018, superimposed with the pathway for anomalous spiciness signals. (d) Hovmöller diagrams of Argo salinity anomalies (shaded) and potential temperature anomalies (contours) along point stations are shown in (c). High-frequency signals are removed by applying a 3-yr running mean.

In this study, we investigate the role of air-sea buoyancy flux and Ekman pumping to understand the thermodynamic and dynamic processes involved in the MLD variability observed during 2004-18. The air-sea heat exchange and surface winds from both ERA5 and NCEP2 are used to calculate the sea surface buoyancy flux and Ekman pumping to test the uncertainties due to datasets. The results from ERA5 are consistent with those from NCEP2 (not shown). A decreasing trend of the buoyancy flux occurs in the SAMW formation region during 2004-18. Meanwhile, wind stress curl shows a positive trend in the SAMW formation region during 2004-18. Our results indicate that the increasing trend of the L-SAMW subduction rate can be explained by strengthening downward Ekman pumping and buoyancy loss via more robust mixing during 2004-18.

A subduction-heaving-transformation sequence is proposed to explain the volume balance of the water masses in the interior ocean, and this is regarded as the primary mechanism driving the volume variability of the SAMW (Portela et al. 2020). It suggests that the transformation rates not only result from ocean surface buoyancy fluxes, but also from diapycnal mixing in the ocean interior. Diapycnal mixing is well known to be important near the ocean's surface and bottom (Cerovečki et al. 2013; Rintoul 2018; Rintoul and Naveira Garabato 2013; Abernathey et al. 2016). In addition, the importance of diapycnal mixing for water transport has been reported at intermediate depths of $500-1000 \mathrm{~m}$ in certain conditions (Garabato et al. 2004; Portela et al. 2020). Cerovečki and Mazloff (2016) assess the role of air-sea buoyancy fluxes and diapycnal mixing in the SAMW formation in the density range of $26.7-27.2 \mathrm{~kg} \mathrm{~m}^{-3}$ using the SOSE model results during 2008-10. The formation rate is $7.9 \mathrm{~Sv}$ due to surface buoyancy flux and $8.8 \mathrm{~Sv}$ due to ocean diapycnal mixing, balanced by advective export into the interior ocean. A net transformation between Upper Circumpolar Deep Water and the lighter Antarctic Intermediate Water/SAMW layers is found by estimating water mass conversion at the surface and within the interior ocean (Downes et al. 2011; Lumpkin and Speer 2007; Sloyan and Rintoul 2001b). More recently, Portela et al. (2020) suggest that the diapycnal transformation from the lower to the upper layers plays an essential role in the SAMW upper-layer volume gain.

\section{Summary}

A gridded Argo dataset is used to investigate the formation and property variations of the SAMW and their impacts on spiciness in the subtropical SIO during 2004-18. A warming/salinification trend of the SAMW is observed, within a two-layer structure, consisting of relatively thicker layer of more warm, salty and light SAMW and a thinner layer of cool, fresh and dense SAMW, during the period of observation. The decomposition of temperature and salinity anomalies shows that both heaving and spiciness are essential for the observed changes in the SAMW properties. The warming/salinification contribution from heaving is more substantial than the cooling/freshening contribution from spiciness. Thus, an overall warming/salinification trend of the SAMW is detected in the SIO. 
(a) T of ML-SAMW 2004-09

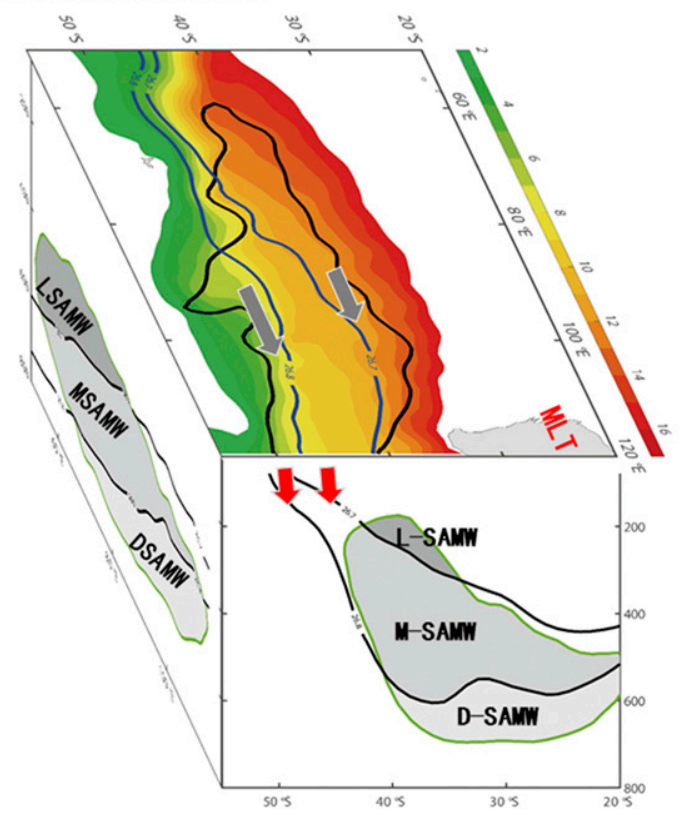

(b) T of ML (2010-15)-SAMW (2013-18)

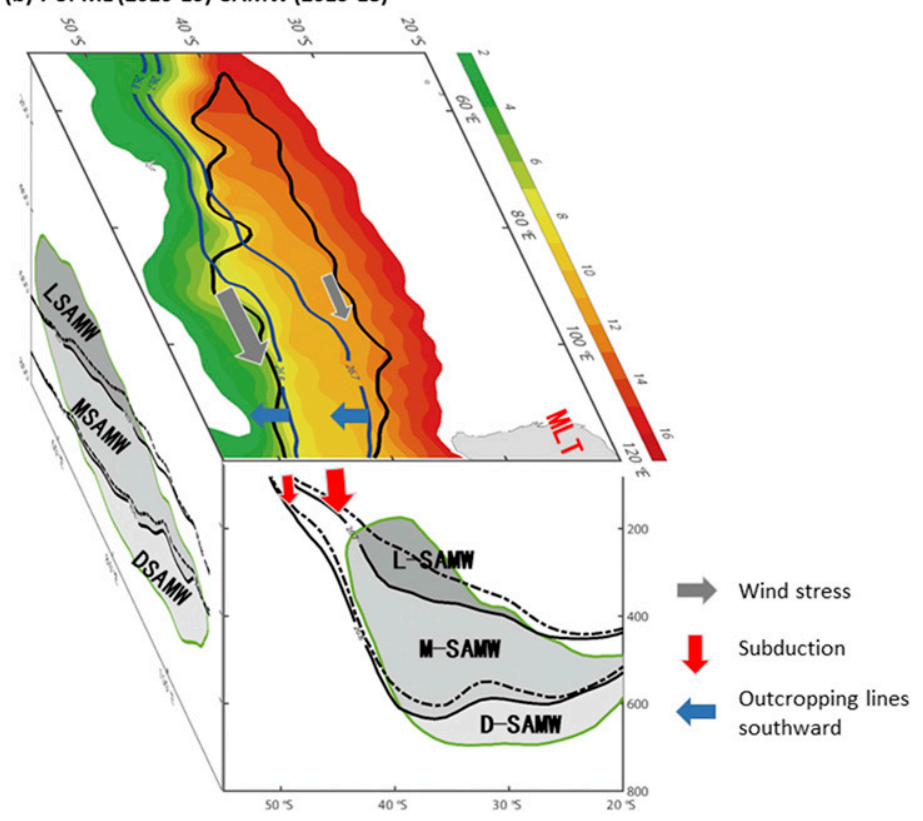

FIG. 13. Schematic diagram of changes in the SAMW properties and formation. (a) Surface: climatological mean winter mixed layer temperature (shaded), deep mixed layer at a depth of $150 \mathrm{~m}$ (black contour), and potential density (blue contours) during 2004-09; subsurface: different classes of the SAMW (shaded) and potential density (black solid contours) during 2004-09, and climatological mean low PV (enclosed green contour). (b) As in (a), but for 2010-15 (mixed layer) and 2013-18 (subsurface). Black dashed contours in (b) denote potential density averaged during 2004-09. Color and corresponding areas in the subsurface low PV (enclosed green contour) represent average temperature and volume of different classes of the SAMW, respectively.

The intensifying wind stress curl over the Subantarctic Zone leads to the deepening of the isopycnal surfaces of the SAMW during 2004-18. This deepening of isopycnal surfaces is also supported by the surface buoyancy flux loss during 2004-18. The maximum deepening of the isopycnal surfaces is found in the M-SAMW, favoring not only an increase in the volume of the warm and salty L-SAMW but also a decrease in the volume of the cool and fresh D-SAMW (Fig. 13).

The cooling/freshening contribution from the spiciness process is mainly due to a southward displacement of density outcropping lines, which induces the subduction of colder and fresher water from the south. The southward displacement of density outcropping lines in the SAMW formation region during 2010-15 is due to the increased mixed layer temperature during winter.

The subducted colder and fresher water spreads along isopycnal surfaces via the subtropical gyre, which results in a cooling/freshening spiciness trend over much of the subtropical SIO during 2004-18.

Our results suggest that the 15-yr-long trends of the SAMW properties involve both dynamic and thermodynamic processes. The decomposition of changes in the SAMW properties into heaving and spiciness processes relates closely to climate variability, ocean ventilation, and air-sea interaction induced thermohaline shifts. The SAMW transmits surface signals at high latitudes into the ocean interior toward lower latitudes, providing important memory for climate variability and anthropogenic change. The changes of ocean temperature and salinity caused by ocean ventilation and air-sea forced thermohaline shifts are quite significant but with opposite signs under current climate change; however, this cannot be displayed in Cartesian coordinates. Further investigations using particle tracking (Lange and van Sebille 2017) in conjunction with climate model simulations (Eyring et al. 2016), and more attention to the dynamics and thermodynamics drivers, will help to increase understanding of presentday and future SAMW changes, and therefore of our changing climate system.

Acknowledgments. This study is supported by the National Natural Science Foundation of China (42006026, 42090042, 41906180, and 41830538), the Natural Science Foundation of Guangdong Province, China (2020A1515010361), the Chinese Academy of Sciences (XDB42010304, XDA15020901, 133244KYSB20190031, LTOZZ2005, and XDA19060501), and the Southern Marine Science and Engineering Guangdong Laboratory (Guangzhou) (GML2019ZD0303, and 2019BT02H594). T. Qu was supported by the NSF through Grant 1829809. CMD was partially supported by an ARC Future Fellowship FT130101532, an ARC Discovery Project (DP160103130), and the Transient tracer-based Investigation of circulation and Thermal Ocean Change (TICTOC; NERC Grant NE/P019293/2).

Data availability statement. Argo data were collected and made freely available by the International Argo Program and the national programs that contribute to it (http://www.argo.ucsd.edu, http://argo.jcommops.org). The ERA5 dataset is provided by 
CMEMS at https://cds.climate.copernicus.eu/cdsapp\#!/dataset/ reanalysis-era5-single-levels-monthly-means?tab $=$ form. The GPCP precipitation is obtained from NASA/GSFC (http:// precip.gsfc.nasa.gov). The OAFlux evaporation is available at http://oaflux.whoi.edu.

\section{REFERENCES}

Abernathey, R. P., I. Cerovecki, P. R. Holland, E. Newsom, M. Mazloff, and L. D. Talley, 2016: Water-mass transformation by sea ice in the upper branch of the Southern Ocean overturning. Nat. Geosci., 9, 596-601, https://doi.org/10.1038/ ngeo2749.

Adler, R., and Coauthors, 2016: The new version 2.3 of the Global Precipitation Climatology Project (GPCP) monthly analysis product. University of Maryland, 8 pp., http:// apdrc.soest.hawaii.edu/doc/GPCPmonthlyV2.3.pdf.

Arbic, B. K., and W. Brechner Owens, 2001: Climatic warming of Atlantic intermediate waters. J. Climate, 14, 4091-4108, https://doi.org/10.1175/1520-0442(2001)014<4091:CWOAIW> 2.0.CO;2.

Banks, H., R. Wood, and J. Gregory, 2002: Changes to Indian Ocean subantarctic mode water in a coupled climate model as $\mathrm{CO}_{2}$ forcing increases. J. Phys. Oceanogr., 32, 2816-2827, https://doi.org/10.1175/1520-0485(2002)032<2816:CTIOSM> 2.0.CO;2.

Bindoff, N. L., and J. A. Church, 1992: Warming of the water column in the southwest Pacific Ocean. Nature, 357, 59-62, https://doi.org/10.1038/357059a0.

-_ , and T. J. McDougall, 1994: Diagnosing climate change and ocean ventilation using hydrographic data. J. Phys. Oceanogr., 24, 1137-1152, https://doi.org/10.1175/15200485(1994)024<1137:DCCAOV>2.0.CO;2.

Bryden, H. L., M. J. Griffiths, A. M. Lavin, R. C. Millard, G. Parrilla, and W. M. Smethie, 1996: Decadal changes in water mass characteristics at $24^{\circ} \mathrm{N}$ in the subtropical North Atlantic Ocean. J. Climate, 9, 3162-3186, https://doi.org/ 10.1175/1520-0442(1996)009<3162:DCIWMC > 2.0.CO;2.

_ - E. L. McDonagh, and B. A. King, 2003: Changes in ocean water mass properties: Oscillations or trends? Science, 300, 2086-2088, https://doi.org/10.1126/science.1083980.

Bye, J. A. T. 1972: Oceanic circulation south of Australia. Antarctica Oceanology II: The Australian-New Zealand Sector, D. E. Hayes, Ed., Antarctic Research Series, Vol. 19, Amer. Geophys. Union, 95-100, https://doi.org/10.1029/AR019p0095.

_ 1983: The general circulation in a dissipative ocean basin with longshore wind stresses. J. Phys. Oceanogr., 13, 1553-1563, https://doi.org/10.1175/1520-0485(1983)013<1553:TGCIAD> 2.0.CO;2.

Cerovečki, I., and M. R. Mazloff, 2016: The spatiotemporal structure of diabatic processes governing the evolution of subantarctic mode water in the Southern Ocean. J. Phys. Oceanogr., 46, 683-710, https://doi.org/10.1175/JPO-D-14-0243.1.

— L. D. Talley, M. R. Mazloff, and G. Maze, 2013: Subantarctic mode water formation, destruction, and export in the eddypermitting Southern Ocean state estimate. J. Phys. Oceanogr., 43, 1485-1511, https://doi.org/10.1175/JPO-D-12-0121.1.

Clément, L., E. L. McDonagh, A. Marzocchi, and A. J. G. Nurser, 2020: Signature of ocean warming at the mixed layer base. Geophys. Res. Lett., 47, e2019GL086269, https://doi.org/ 10.1029/2019GL086269.

de Boyer Montégut, C., G. Madec, A. S. Fischer, A. Lazar, and D. Iudicone, 2004: Mixed layer depth over the global ocean:
An examination of profile data and a profile-based climatology. J. Geophys. Res., 109, C12003, https://doi.org/10.1029/ 2004JC002378.

Desbruyères, D., E. L. McDonagh, B. A. King, and V. Thierry, 2017: Global and full-depth ocean temperature trends during the early twenty-first century from Argo and repeat hydrography. J. Climate, 30, 1985-1997, https://doi.org/10.1175/JCLID-16-0396.1.

DeVries, T., M. Holzer, and F. Primeau, 2017: Recent increase in oceanic carbon uptake driven by weaker upper-ocean overturning. Nature, 542, 215-218, https://doi.org/10.1038/ nature21068.

Dong, S., S. T. Gille, and J. Sprintall, 2007: An assessment of the Southern Ocean mixed layer heat budget. J. Climate, 20, 4425-4442, https://doi.org/10.1175/JCLI4259.1.

_ J. Sprintall, S. T. Gille, and L. Talley, 2008: Southern Ocean mixed-layer depth from Argo float profiles. J. Geophys. Res., 113, C06013, https://doi.org/10.1029/2006JC004051.

Downes, S. M., N. L. Bindoff, and S. R. Rintoul, 2009: Impacts of climate change on the subduction of mode and intermediate water masses in the Southern Ocean. J. Climate, 22, 32893302, https://doi.org/10.1175/2008JCLI2653.1.

,-- , and _ 2010: Changes in the subduction of Southern Ocean water masses at the end of the twenty-first century in eight IPCC models. J. Climate, 23, 6526-6541, https://doi.org/ 10.1175/2010JCLI3620.1.

_, A. S. Budnick, J. L. Sarmiento, and R. Farneti, 2011: Impacts of wind stress on the Antarctic Circumpolar Current fronts and associated subduction. Geophys. Res. Lett., 38, L11605, https://doi.org/10.1029/2011GL047668.

_- C. Langlais, J. P. Brook, and P. Spence, 2017: Regional impacts of the westerly winds on Southern Ocean mode and intermediate water subduction. J. Phys. Oceanogr., 47, 25212530, https://doi.org/10.1175/JPO-D-17-0106.1.

Eyring, V., S. Bony, G. A. Meehl, C. A. Senior, B. Stevens, R. J. Stouffer, and K. E. Taylor, 2016: Overview of the Coupled Model Intercomparison Project Phase 6 (CMIP6) experimental design and organization. Geosci. Model Dev., 9, 19371958, https://doi.org/10.5194/gmd-9-1937-2016.

Fine, R. A., 1993: Circulation of Antarctic intermediate water in the South Indian Ocean. Deep-Sea Res. I, 40, 2021-2042, https://doi.org/10.1016/0967-0637(93)90043-3.

— W. M. Smethie, J. L. Bullister, M. Rhein, D.-H. Min, M. J. Warner, A. Poisson, and R. F. Weiss, 2008: Decadal ventilation and mixing of Indian Ocean waters. Deep-Sea Res. I, 55, 20-37, https://doi.org/10.1016/j.dsr.2007.10.002.

Gao, L. B., S. R. Rintoul, and W. D. Yu, 2018: Recent wind-driven change in Subantarctic Mode Water and its impact on ocean heat storage. Nat. Climate Change, 8, 58-63, https://doi.org/ 10.1038/s41558-017-0022-8.

Garabato, A. C., K. L. Polzin, B. A. King, K. J. Heywood, and M. Visbeck, 2004: Widespread intense turbulent mixing in the Southern Ocean. Science, 303, 210-213, https://doi.org/ 10.1126/science.1090929.

Häkkinen, S., P. B. Rhines, and D. L. Worthen, 2016: Warming of the global ocean: Spatial structure and water-mass trends. J. Climate, 29, 4949-4963, https://doi.org/10.1175/JCLI-D15-0607.1.

Hall, A., and M. Visbeck, 2002: Synchronous variability in the Southern Hemisphere atmosphere, sea ice, and ocean resulting from the annular mode. J. Climate, 15, 30433057, https://doi.org/10.1175/1520-0442(2002)015<3043: SVITSH $>2.0 . \mathrm{CO} ; 2$. 
Hanawa, K., and L. D. Talley, 2001: Mode waters. Int. Geophys. Series, 77, 373-386, https://doi.org/10.1016/S0074-6142(01)80129-7.

Hartmann, D. L., and F. Lo, 1998: Wave-driven zonal flow vacillation in the Southern Hemisphere. J. Atmos. Sci., 55, 1303-1315, https:// doi.org/10.1175/1520-0469(1998)055<1303:WDZFVI >2.0.CO;2.

Herraiz-Borreguero, L., and S. R. Rintoul, 2011: Subantarctic mode water: Distribution and circulation. Ocean Dyn., 61, 103-126, https://doi.org/10.1007/s10236-010-0352-9.

Holte, J. W., L. D. Talley, T. K. Chereskin, and B. M. Sloyan, 2012: The role of air-sea fluxes in Subantarctic Mode Water formation. J. Geophys. Res., 117, C03040, https://doi.org/10.1029/ 2011JC007798.

Hong, Y., Y. Du, T. Qu, Y. Zhang, and W. Cai, 2020: Variability of the subantarctic mode water volume in the South Indian Ocean during 2004-2018. Geophys. Res. Lett., 47, e2020GL087830, https://doi.org/10.1029/2020GL087830.

$\mathrm{Hu}, \mathrm{S}$., and Coauthors, 2019: Interannual to decadal variability of upper-ocean salinity in the southern Indian Ocean and the role of the Indonesian Throughflow. J. Climate, 32, 6403-6421, https://doi.org/10.1175/JCLI-D-19-0056.1.

Johnson, G. C., and A. H. Orsi, 1997: Southwest Pacific Ocean water-mass changes between 1968/69 and 1990/91. J. Climate, 10, 306-316, https://doi.org/10.1175/1520-0442(1997)010<0306: SPOWMC $>2.0 . \mathrm{CO} ; 2$.

Jones, D. C., A. J. S. Meijers, E. Shuckburgh, J.-B. Sallée, P. Haynes, E. K. McAufield, and M. R. Mazloff, 2016: How does Subantarctic Mode Water ventilate the Southern Hemisphere subtropics? J. Geophys. Res. Oceans, 121, 6558-6582, https://doi.org/10.1002/2016JC011680.

Karstensen, J., and M. Tomczak, 1997: Ventilation processes and water mass ages in the thermocline of the southeast Indian Ocean. Geophys. Res. Lett., 24, 2777-2780, https://doi.org/ 10.1029/97GL02708.

— , and — 1998: Age determination of mixed water masses using CFC and oxygen data. J. Geophys. Res., 103, 18599 18609, https://doi.org/10.1029/98JC00889.

— Ocean subtropical gyre. Deep-Sea Res. II, 49, 1441-1457, https://doi.org/10.1016/S0967-0645(01)00160-6.

$\longrightarrow$, and — 2002b: Formation of Southern Hemisphere thermocline waters: Water mass conversion and subduction. J. Phys. Oceanogr., 32, 3020-3038, https://doi.org/10.1175/ 1520-0485(2002)032<3020:FOSHTW >2.0.CO;2.

Koch-Larrouy, A., R. Morrow, T. Penduff, and M. Juza, 2010: Origin and mechanism of Subantarctic Mode Water formation and transformation in the Southern Indian Ocean. Ocean Dyn., 60, 563-583, https://doi.org/10.1007/s10236-010-0276-4.

Kolodziejczyk, N., W. Llovel, and E. Portela, 2019: Interannual variability of upper ocean water masses as inferred from Argo array. J. Geophys. Res. Oceans, 124, 6067-6085, https:// doi.org/10.1029/2018JC014866.

Lange, M., and E. van Sebille, 2017: Parcels v0.9: Prototyping a Lagrangian ocean analysis framework for the petascale age. Geosci. Model Dev., 10, 4175-4186, https://doi.org/10.5194/ gmd-10-4175-2017.

Lee, D. Y., M. R. Petersen, and W. Lin, 2019: The Southern Annular Mode and Southern Ocean surface westerly winds in E3SM. Earth Space Sci., 6, 2624-2643, https://doi.org/ 10.1029/2019EA000663.

Li, Q., and S. Lee, 2017: A mechanism of mixed layer formation in the Indo-Western Pacific Southern Ocean: Preconditioning by an eddy-driven jet-scale overturning circulation. J. Phys. Oceanogr., 47, 2755-2772, https://doi.org/10.1175/JPO-D-17-0006.1.
Li, Y., and F. Wang, 2015: Thermocline spiciness variations in the tropical Indian Ocean observed during 2003-2014. Deep-Sea Res. I, 97, 52-66, https://doi.org/10.1016/j.dsr.2014.12.004.

,$- \ldots$, and F. Zhai, 2012: Interannual variations of subsurface spiciness in the Philippine Sea: Observations and mechanism. J. Phys. Oceanogr., 42, 1022-1038, https://doi.org/10.1175/ JPO-D-12-06.1.

Liu, W., J. Lu, S.-P. Xie, and A. Fedorov, 2018: Southern Ocean heat uptake, redistribution, and storage in a warming climate: The role of meridional overturning circulation. J. Climate, 31, 4727-4743, https://doi.org/10.1175/JCLI-D-17-0761.1.

Llovel, W., and L. Terray, 2016: Observed southern upperocean warming over 2005-2014 and associated mechanisms. Environ. Res. Lett., 11, 124023, https://doi.org/ 10.1088/1748-9326/11/12/124023.

Lovenduski, N. S., 2005: Impact of the Southern Annular Mode on Southern Ocean circulation and biology. Geophys. Res. Lett., 32, L11603, https://doi.org/10.1029/2005GL022727.

Lumpkin, R., and K. Speer, 2007: Global ocean meridional overturning. J. Phys. Oceanogr., 37, 2550-2562, https://doi.org/ 10.1175/JPO3130.1.

Luo, Y., 2005: On the connection between South Pacific subtropical spiciness anomalies and decadal equatorial variability in an ocean general circulation model. J. Geophys. Res., 110, C10002, https://doi.org/10.1029/2004JC002655.

Luyten, J. R., J. Pedlosky, and H. Stommel, 1983: The ventilated thermocline. J. Phys. Oceanogr., 13, 292-309, https://doi.org/ 10.1175/1520-0485(1983)013<0292:TVT>2.0.CO;2.

Marsh, R., A. G. Nurser, A. P. Megann, and A. L. New, 2000a: Water mass transformation in the Southern Ocean of a global isopycnal coordinate GCM. J. Phys. Oceanogr., 30, 1013-1045, https://doi.org/10.1175/1520-0485(2000)030<1013: WMTITS $>2.0 . \mathrm{CO} ; 2$.

— A. J. G. Nurser, A. P. Megann, and A. L. New, 2000b: Water mass transformation in the Southern Ocean of a global isopycnal coordinate GCM. J. Phys. Oceanogr., 30, 1013-1045, https:// doi.org/10.1175/1520-0485(2000)030<1013:WMTITS >2.0.CO;2.

Marshall, D., and J. Marshall, 1995: On the thermodynamics of subduction. J. Phys. Oceanogr., 25, 138-151, https://doi.org/ 10.1175/1520-0485(1995)025<0138:OTTOS > 2.0.CO;2.

Marshall, G. J., 2003: Trends in the southern annular mode from observations and reanalyses. J. Climate, 16, 4134-4143, https:// doi.org/10.1175/1520-0442(2003)016<4134:TITSAM>2.0.CO;2.

Marshall, J. C., R. G. Williams, and A. J. G. Nurser, 1993: Inferring the subduction rate and period over the North Atlantic. J. Phys. Oceanogr., 23, 1315-1329, https://doi.org/10.1175/ 1520-0485(1993)023<1315:ITSRAP > 2.0.CO;2.

McCartney, M., 1979: Subantarctic mode water. Woods Hole Oceanographic Institution Contribution 3773, 103-119.

McCartney, M. S., 1982: The subtropical recirculation of mode waters. J. Mar. Res., 40, 427-464.

McDougall, T. J., 1989: Streamfunctions for the lateral velocity vector in a compressible ocean. J. Mar. Res., 47, 267-284, https://doi.org/10.1357/002224089785076271.

_ , and O. A. Krzysik, 2015: Spiciness. J. Mar. Res., 73, 141-152, https://doi.org/10.1357/002224015816665589.

Middleton, J. F., and J. A. T. Bye, 2007: A review of the shelf-slope circulation along Australia's southern shelves: Cape Leeuwin to Portland. Prog. Oceanogr., 75, 1-41, https://doi.org/10.1016/ j.pocean.2007.07.001.

Montgomery, R. B., 1937: A suggested method for representing gradient flow in isentropic surfaces. Bull. Amer. Meteor. Soc., 18, 210-212, https://doi.org/10.1175/1520-0477-18.6-7.210. 
Nagura, M., and S. Kouketsu, 2018: Spiciness anomalies in the upper South Indian Ocean. J. Phys. Oceanogr., 48, 2081-2101, https://doi.org/10.1175/JPO-D-18-0050.1.

Nonaka, M., and H. Sasaki, 2007: Formation mechanism for isopycnal temperature-salinity anomalies propagating from the eastern South Pacific to the equatorial region. J. Climate, 20, 1305-1315, https://doi.org/10.1175/JCLI4065.1.

Nurser, A. J. G., and J. C. Marshall, 1991: On the relationship between subduction rates and diabatic forcing of the mixed layer. J. Phys. Oceanogr., 21, 1793-1802, https://doi.org/ 10.1175/1520-0485(1991)021<1793:OTRBSR > 2.0.CO;2.

Portela, E., N. Kolodziejczyk, C. Maes, and V. Thierry, 2020: Interior water-mass variability in the Southern-Hemisphere oceans during the last decade. J. Phys. Oceanogr., 50, 361-381, https://doi.org/10.1175/JPO-D-19-0128.1.

Qu, T., I. Fukumori, and R. A. Fine, 2019: Spin-up of the southern hemisphere super gyre. J. Geophys. Res. Oceans, 124, 154-170, https://doi.org/10.1029/2018JC014391.

_- S. Gao, and R. A. Fine, 2020: Variability of the subantarctic mode water subduction rate during the Argo period. Geophys. Res. Lett., 47, e2020GL088248, https:// doi.org/10.1029/2020GL088248.

Rintoul, S. R., 2018: The global influence of localized dynamics in the Southern Ocean. Nature, 558, 209-218, https://doi.org/ 10.1038/s41586-018-0182-3.

— , and S. Sokolov, 2001: Baroclinic transport variability of the Antarctic Circumpolar Current south of Australia (WOCE repeat section SR3). J. Geophys. Res., 106, 2815-2832, https:// doi.org/10.1029/2000JC900107.

_ , and M. H. England, 2002: Ekman transport dominates local air-sea fluxes in driving variability of subantarctic mode water. J. Phys. Oceanogr., 32, 1308-1321, https://doi.org/10.1175/ 1520-0485(2002)032<1308:ETDLAS > 2.0.CO;2.

— , and A. C. N. Garabato, 2013: Dynamics of the Southern Ocean circulation. Ocean Circulation and Climate: A 21st Century Perspective, International Geophysics Series, Vol. 103, Academic Press, 471-492, https://doi.org/10.1016/B978-012-391851-2.00018-0.

Roemmich, D., and J. Gilson, 2009: The 2004-2008 mean and annual cycle of temperature, salinity, and steric height in the global ocean from the Argo Program. Prog. Oceanogr., 82, 81-100, https://doi.org/10.1016/j.pocean.2009.03.004.

_ J. Church, J. Gilson, D. Monselesan, P. Sutton, and S. Wijffels, 2015: Unabated planetary warming and its ocean structure since 2006. Nat. Climate Change, 5, 240-245, https://doi.org/10.1038/ nclimate2513.

Sabine, C. L., and Coauthors, 2004: The oceanic sink for anthropogenic $\mathrm{CO}_{2}$. Science, 305, 367-371, https://doi.org/10.1126/ science. 1097403.

Sallée, J. B., and S. R. Rintoul, 2011: Parameterization of eddy-induced subduction in the Southern Ocean surface-layer. Ocean Modell., 39, 146-153, https://doi.org/10.1016/j.ocemod.2011.04.001.

__, N. Wienders, K. Speer, and R. Morrow, 2006: Formation of subantarctic mode water in the southeastern Indian Ocean. Ocean Dyn., 56, 525-542, https://doi.org/10.1007/ s10236-005-0054-x.

_, R. Morrow, and K. Speer, 2008a: Eddy heat diffusion and subantarctic mode water formation. Geophys. Res. Lett., 35, L05607, https://doi.org/10.1029/2007GL032827.

- - , K. G. Speer, and R. Morrow, 2008b: Response of the Antarctic Circumpolar Current to atmospheric variability. J. Climate, 21, 3020-3039, https://doi.org/10.1175/ 2007JCLI1702.1.
,-- , and S. R. Rintoul, 2010a: Zonally asymmetric response of the Southern Ocean mixed-layer depth to the Southern Annular Mode. Nat. Geosci., 3, 273-279, https://doi.org/ 10.1038/ngeo812.

,,,--- and S. Wijffels, 2010b: Southern Ocean thermocline ventilation. J. Phys. Oceanogr., 40, 509-529, https:// doi.org/10.1175/2009JPO4291.1.

_ _ R. J. Matear, S. R. Rintoul, and A. Lenton, 2012: Localized subduction of anthropogenic carbon dioxide in the Southern Hemisphere oceans. Nat. Geosci., 5, 579-584, https://doi.org/ $10.1038 /$ ngeo1523.

Sarmiento, J. L., N. Gruber, M. Brzezinski, and J. Dunne, 2004: High-latitude controls of thermocline nutrients and low latitude biological productivity. Nature, 427, 56-60, https:// doi.org/10.1038/nature02127.

Schneider, N., 2000: A decadal spiciness mode in the tropics. Geophys. Res. Lett., 27, 257-260, https://doi.org/10.1029/ 1999GL002348.

Sloyan, B. M., and S. R. Rintoul, 2001a: The Southern Ocean limb of the global deep overturning circulation. J. Phys. Oceanogr., 31, 143-173, https://doi.org/10.1175/1520-0485(2001)031<0143: TSOLOT $>2.0 . \mathrm{CO} ; 2$.

$\longrightarrow$, and — 2001b: Circulation, renewal, and modification of Antarctic mode and intermediate water. J. Phys. Oceanogr., 31, 1005-1030, https://doi.org/10.1175/1520-0485(2001)031<1005: CRAMOA $>2.0 . \mathrm{CO} ; 2$.

—, L. D. Talley, T. K. Chereskin, R. Fine, and J. Holte, 2010: Antarctic intermediate water and subantarctic mode water formation in the southeast Pacific: The role of turbulent mixing. J. Phys. Oceanogr., 40, 1558-1574, https://doi.org/10.1175/ 2010JPO4114.1.

Speer, K., S. Rintoul, and B. Sloyan, 1997: Subantarctic mode water formation by air-sea fluxes. International WOCE Newsletter, No. 27, WOCE International Project Office, Southampton, United Kingdom, 29-31.

Speer, K. G., and G. Forget, 2013: Global distribution and formation of mode waters. Ocean Circulation and Climate: A 21st Century Perspective, G. Siedler et al., Eds., International Geophysics, Vol. 103, Elsevier, 211-226, https://doi.org/10.1016/ B978-0-12-391851-2.00009-X.

Talley, L. D., 1999: Some aspects of ocean heat transport by the shallow, intermediate and deep overturning circulations. Geophys. Mono. Ser, 112, 1-22, https://doi.org/ 10.1029/GM112p0001.

— 2013: Closure of the global overturning circulation through the Indian, Pacific, and Southern Oceans: Schematics and transports. Oceanography, 26, 80-97, https://doi.org/10.5670/ oceanog.2013.07.

Thompson, D. W. J., and J. M. Wallace, 2000: Annular modes in the extratropical circulation. Part I: Month-to-Month variability. J. Climate, 13, 1000-1016, https://doi.org/10.1175/ 1520-0442(2000)013<1000:AMITEC>2.0.CO;2.

Thompson, R. O., and R. Edwards, 1981: Mixing and water-mass formation in the Australian subantarctic. J. Phys. Oceanogr., 11, 1399-1406, https://doi.org/10.1175/1520-0485(1981)011<1399: MAWMFI $>2.0 . \mathrm{CO} ; 2$.

Wong, A. P. S., 2005: Subantarctic mode water and Antarctic intermediate water in the South Indian Ocean based on profiling float data 2000-2004. J. Mar. Res., 63, 789-812, https://doi.org/ $10.1357 / 0022240054663196$.

, N. L. Bindoff, and J. A. Church, 1999: Large-scale freshening of intermediate waters in the Pacific and Indian Oceans. Nature, 400, 440-443, https://doi.org/10.1038/22733. 
Yang, H., G. Lohmann, W. Wei, M. Dima, M. Ionita, and J. Liu, 2016: Intensification and poleward shift of subtropical western boundary currents in a warming climate. J. Geophys. Res. Oceans, 121, 4928-4945, https://doi.org/ 10.1002/2015JC011513.

Yeager, S. G., and W. G. Large, 2004: Late-winter generation of spiciness on subducted isopycnals. J. Phys. Oceanogr., 34, 1528-1547, https://doi.org/10.1175/1520-0485(2004)034<1528: LGOSOS $>2.0 . \mathrm{CO} ; 2$.

, and - 2007: Observational evidence of winter spice injection. J. Phys. Oceanogr., 37, 2895-2919, https://doi.org/ 10.1175/2007JPO3629.1.
You, Y., 1996: Dianeutral mixing in the thermocline of the Indian Ocean. Deep-Sea Res. I, 43, 291-320, https://doi.org/10.1016/ 0967-0637(96)00007-6.

Yu, L., X. Jin, and R. A. Weller, 2008: Multidecade global flux datasets from the Objectively Analyzed Air-Sea Fluxes (OAFlux) Project: Latent and sensible heat fluxes, ocean evaporation, and related surface meteorological variables. Woods Hole Oceanographic Institution OAFlux Project Tech. Rep. OA-2008-01, 64 pp.

Zhang, Y., M. Feng, Y. Du, H. E. Phillips, N. L. Bindoff, and M. J. McPhaden, 2018: Strengthened Indonesian Throughflow drives decadal warming in the southern Indian Ocean. Geophys. Res. Lett., 45, 6167-6175, https://doi.org/10.1029/2018GL078265. 